\title{
Corporate Governance: Theoretical Analysis and Examination of a Sample of 22 Companies in French Guyana
}

\author{
Paul Roselé Chim \\ University of Paris Ouest Nanterre La Défense \\ University of Paris-Pantheon Sorbonne \\ Beta Emadd Bio Minea UR 7485 \\ University of French Guiana
}

\begin{abstract}
Governance plays an essential role in the functioning and performance improvement of companies, which define their governance structure in order to adapt to changes in the environment. Imposing identical governance rules on all companies can disrupt or even destabilize a governance system that is otherwise globally coherent and efficient. Choosing a system of governance means that the mechanisms of the company control the actions of the managers and analyze them as fulfilling their obligations to the principals, the shareholders. Thus, two groups stand out, namely the managers and the shareholders. So, how to satisfy all parties correctly? What management objectives should be attributed to managers? What guarantee can we have on the sincerity of the executive power on the social interest? This paper proposes to answer these three questions by examining governance through the study of a sample of 22 firms in French Guyana. It examines the literature on corporate governance, and the link between theories and contractualization, to conduct the quantitative investigation, and interpretation of the results.
\end{abstract}

Keywords: corporate governance, shareholders, industrial firms, stakeholder theory

\section{INTRODUCTION}

Governance is a key element in the company's policy. It influences the partners and aims to improve performance. The OECD recalls that it is "a set of relationships between management, its board of directors, its shareholders and other stakeholders". Some authors believe that governance remains "the set of mechanisms that have the effect of limiting the power and influencing the decisions of managers." It is therefore the act of governing one's conduct and defining discretionary space.

Thus, choosing a system of governance means ensuring that the firm's mechanisms control the actions of its managers and analyze them as fulfilling their obligations towards their principals and shareholders. Thus, two groups stand out, namely managers and shareholders, as reflected in the emergence of financial markets. Banks in terms of holding shares in companies will privilege the interests of shareholders, the main goal being profit maximization.

If the company does not perform well enough, minority shareholders will then decide to sell their shares. The risks of hostile takeovers (takeover bids) are then higher, as is the ousting of a hostile takeover that encourages rational management of shareholders' interests. 
Stakeholder governance is a more recent form of governance that focuses on stakeholders inside or outside the company. The objective is not to maximize profit for shareholders but to distribute this wealth for all stakeholders (employees, customers, shareholders, management, community, bank). It is then its capacity to regulate conflicts in the distribution of organizational rent.

This model of governance means that the financial market is not very operational. The majority shareholders are in control of the company, in particular through the share of capital in the company as individuals. However, it should also be noted that the stakeholders (banks, unions, customers) verify the actions of the managers. This governance therefore participates in the creation of the company's wealth while at the same time highlighting the needs of all participants. It will seek to satisfy the interests of the various parties because their involvement in the smooth running of the company for the contribution to wealth will pass through all of them.

The central problem remains that of sharing the organizational rent. Whatever the mode of governance, the distribution of the wealth created becomes a recurring problem because these actors (shareholders, managers and stakeholders) all have different interests.

So, how can all parties be properly satisfied? What management objectives should be assigned to the managers? What guarantee can we have about the sincerity of the executive power over the social interest?

This paper proposes to answer these three questions by examining governance through a study of a sample of 22 companies in French Guyana. It proceeds from an entry into the literature on corporate governance, and an examination of the link between theories and contractualization, to conduct the quantitative investigation, that's to say a survey, calculations and interpretation of the results.

\section{PROLOGUE IN THE CORPORATE GOVERNANCE LITERATURE}

The notion of "governance" has a long history dating back to Ancient Greece. It derives from the concept "kubernân" which means "to pilot a ship or a tank". Platon uses the Latin concept "gubernantia" in his writings on the Republic, to refer to the act of governing men.

Governance, through the term "government" associated with qualifiers, expresses various meanings as examples: associative governance, global governance, territorial governance, corporate governance. We focus on the latter.

It was after the 1929 crisis that Berle and Means' (1932) first analyses appeared, in which ownership and management of the firm were treated as legally separate. The shareholders are led to assume the risks of a management for which they have no guarantee and the managers have the power of daily management of the company which does not belong to them.

This particular circumstance would not have been a concern if there had not been disagreements between shareholders and managers as to the interests of each. Indeed, the division of ownership and decision-making functions is a source of many problems. The shareholder, by committing his personal fund to a company, assumes the risk of losing it but hopes to maximize his investment. While the manager who does not own the business will want to maximize his own interest.

The way in which the people or organizations that finance a company ensure that they receive a return on their investment is a reflection of corporate governance. In this regard, the central issue is the sharing of powers and responsibilities (Shleifer, Vishny) (1997), (Caby, Hirigoyen) (2005). Charreaux (2005), Finet (2005) think that shareholders have the power to influence managers, hence the idea of regulation by decisions taken by managers, whereas it is also, indeed, in the interest of shareholders. One understands the desire to maximize the company's profit.

There are other stakeholders such as suppliers, customers, employees, bankers, central or local government and the environment. They are stakeholders in the sense defined by Charreaux (1996) and Clarke (1998), we say all agents or groups of agents who have a legitimate claim on the firm whose origin is linked to a relationship of exchange concerning the resources contributed by the various stakeholders at the material, financial, human and public infrastructural level where the products or services are purchased and consumed. 
Partnership governance, which has the opinion of the stakeholders, has called into question the objective of maximizing shareholder value (Hirigoyen) (1997). (Hill and Jones) (1992) took their views into account in agency theory. In such circumstances, the manager should be in control and bring the interests of both parties together to avoid conflict. The growth of the firm may depend on two factors : the financial contribution of the shareholders and the skills of its employees. However, Masahiko Aoki (1984), considers that the role of the manager is to guarantee the functioning of the firm by controlling work, human and financial resources. The objectives of the two parties being different, on decision making such as the distribution of profitability, operations and investment, Williamson (1985) will define "corporate governance" as a structure governing the transactions that occur between the firm and its managers. We could therefore define corporate governance as "a set of mechanisms" aimed at disciplining management and reducing agency costs. The work of Jensen and Meckling (1976), Fama (1980), (Fama and Jensen) (1983) will give much attention to the internal and external mechanisms that have become essential for reducing conflicts between managers and shareholders. The risks they incur mean that shareholders must put in place verification processes to protect their interests in the event of a wait-and-see attitude on the part of management. The notion of management control within the company is growing in importance and is becoming a major debate on managerial efficiency. The growth of institutional investors in the development of companies, the financial and stock market collapse and fraudulent methods at the managerial level may be the main reasons.

\section{From Managerial to Shareholder Governance}

The freedom of negotiation of the unions and the introduction of taxation of income and inheritances explain the path from managerial governance to shareholder governance. Galbraith (1967) indicates that the agreements that result from negotiations have a significant impact on companies because managers are led to take power at the expense of shareholders. The management was managerial in the sense that managers had to implement a strategy that was to increase profits or the number of employees allowing more guarantees in the company, rather than to satisfy shareholders in terms of profitability. Hence, the manager shares the productivity gains with the employees. The profit rate of companies decreased during the period 1960-1980 (Plihon) (2003).

The liberalization of the financial markets and the power of the unions account for the deterioration of agreements between managers and employees due to a kind of conservative revolution in industrialized countries concerning the reduction of income and wealth taxes. The "3D" concept, in reference to decompartmentalization, disintermediation, and deregulation constitutes the root of the phenomenon of financial globalization, the latter playing the role of intermediary due to the rapid development of information and communication technologies in the 1990s:

- Decompartmentalization corresponds to the elimination of segmentation between deposit and withdrawal banks. The concentration and repositioning of these traditional players leads to the free movement of capital made possible by the abolition of exchange controls and the suppression of measures to prevent the globalization of banks.

- Deregulation leads to the abolition of regulations and controls on the prices of banking services. Financial flows flow more smoothly.

- Disintermediation reinforces firms' direct access to financing through securities issuance rather than debt. Banks transform loans to clean up their balance sheets and financial products. The latter are resold to individuals and pension funds. This is called "securitization".

The notion of "3D" as a reform has given more power to investors by promoting the circulation of capital and competition from savings vehicles. The concentration of capital in the hands of "zinzins" changes the structure of the shareholding. The central role played by certain categories of actors presides over the emergence of new behavioral norms and new organizational forms. A triple delegation is gradually being established, namely from savers to pension funds, from pension funds to fund managers, and from fund managers to selected companies. These agency relationships in imperfect information, due to the possibilities of recourse of the mandates, lead the agents to emphasize the transparency of the procedures allowing them to possibly justify their management. Managers break their agreement with employees and 
get closer to shareholders by benefiting from stock options. The fate of managers is now linked to the share price, hence the move to shareholder governance (Chandler) (1988).

\section{Financialization}

The lessons of the end of the 1980s and 1990s focus attention on the expansion of mergers, absorptions, acquisitions, growth operations in the sectors of New Information and Communication Technologies and traditional industrial branches such as banking, industry and distribution. These operations lead to the development of the financial markets which push the expansion of firms to the great harm of traditional methods of financing credit institutions. The operations pushed aside debt financing from credit institutions but favored financial investors, at the forefront of which are the large Anglo-Saxon pension funds. The Anglo-Saxon model of corporate governance spread thanks to the imposing position of these investors in the financing of European companies. By coordinating their structures and assigning more stringent rules to management teams in terms of transparency and concern for the interests of shareholders, this model of corporate governance was applied due to the colossal lack of external financing for European companies. The obligation of profitability, which is quite consequent, constitutes its central core, but also the performance of the manager measured through financial indicators such as "shareholder value" or "EVA" economic added value. It has been developed for listed companies and taken over by non-listed companies.

\section{Governance in Crisis}

The first phenomenon that has had a heavy impact on the Anglo-Saxon corporate governance model is the financial crisis of the early 2000-2010 decade. It will not be called into question in its actions. The explanation is found in the irrational swelling of the value of shares of companies in the "New Economy", i.e. in the NICT (New Information and Communication Technologies) (Roselé Chim) (2001) (2009) and biotechnology sectors, high-tech start-ups, and Internet GAFAM firms (Roselé Chim) (2012) (2019). However, despite the fall in NICT values (Roselé Chim) (2007), in terms of earnings, share prices rise sharply, causing a speculative bubble. The subprime crisis remains the most striking phenomenon in the banking and financial system.

Fraudulent methods are found in corporate governance, such as the scandals over illicit accounting methods. These have often led to the closure of the companies concerned, as they highlighted the restrictions on the effectiveness of governance systems. These collapses in relation to the financial crisis, creating negative consequences for households, showed that the manager, with the help of auditors, could deliberately hide accounts to the disadvantage of shareholders, employees, supplier creditors, in other words all stakeholders. Thus, it has been possible to illuminate the faking of financial information to promulgate false performance data and defraud shareholders, whereas these are mechanisms to warn of the dangers of spoliation. Corporate affairs have thus revealed the shortcomings of the control and regulation mechanisms that are at the heart of the stock market model of shareholder governance, hence the questioning : Is compensation a source of performance or a source of fraud?

According to agency theory (Jensen and Meckling 1976; Fama and Jensen 1983), compensation is a power that executives possess to improve their interests and those of shareholders. In this way, agency conflicts are reduced. Savage (2009) points out that during a crisis phase, when incentive compensation represents a significant portion of total compensation where the focus is on short-term performance, the risk of executive fraud increases. Nonetheless, payment based on shares or stock options can disrupt executives' initial intentions, increase the risk of financial fraud and harm shareholders (Johnson et al., 2009). Empirical investigations into the link between fraud and stock-based compensation will not be able to reach an agreement. Erickson et al. (2006) studied the relationship between stock-based compensation policy and the probability of fraud. When the executive holds shares or options, the risk of fraud literally increases and represents only part of its totality according to Harris \& Bromiley (2007). Zhang and al. (2008) demonstrate that all non-cash acquisitions can be sources of very significant fraud. Johnson et al. (2009) clarify the method of compensation, proving that the granting of compensation to executives such as shares or options will not have the same consequences. Compensation in the form of shares increases the risk of fraud in the financial statements, whereas the granting of stock options does not affect it. And, 
Ndofor and al. (2013) confirm the analyses of Johnson et al. (2009) on the fact that the fraudulent methods used by executives are mainly due to the holding of options.

The approach of the work retained indicates that option-based compensation is rather an incentive to illicit methods than that of agreeing on the interests of executives to those of shareholders. Few analysts such as Armstrong and al (2010) agree that fraud is exceptional when compensation is a way for shareholders to achieve their ends.

\section{GOVERNANCE AND CONTRACTUALIZATION IN THEORIES}

The examination of economic theories is essential in the emerging explanation of contractualization.

\section{The Microeconomic Approach and Neo-Classical Finance}

It emphasizes the figure of the leader. The shareholders are owners of the firm in the sense that the reference arguments of the managerial decision are operated within a microeconomic framework Montmorillon (2002). Neo-classical financial theory confirms their principle of enrichment, hence the fact that Walras' model remains the most dominant paradigm. It consists of :

- The analysis of the requirements of the balance in a situation of competition and perfect information as well as, for a given state, of techniques.

- The hypothesis of the perfect logic of managers, so that firms can maximize their profit.

- The primacy devoted to the study of transactions over that of operations.

Business is perceived in the sense of a black box using factors to produce market goods and services. It presents an appearance that is difficult to see from a theoretical perspective: the explanation of profit maximization and factor management. Like the principle of the pure and perfect competition model, there are still shadows in relation to reality. Hence, the abundance of approaches giving more credit and realism to the company.

Baumol (1959) and Marris (1964) go into greater depth on the continuity of the advances of Berle and Means (1932,) regarding the difference in the objectives of managers and shareholders, the desire of these two categories being different. Managers seek to maximize their utility functions, while shareholders seek to maximize profit. This observation has its origins in the work of Adam Smith (1776) and Karl Marx (1864) (1875).

We can recall the existence of important breaks in the representation of attitudes and management in a context of rationality. The reasons for pragmatism are threefold:

- The complications of scepticism and imperfect information are not designed by tools of decision theory.

- Restrictions on household means arrangements make it difficult to count the agreements of possible actions and their consequences, hence the tenacity of "optimal" action.

- The specific constraints posed by the circumstances of strategic agreements in oligopolistic competition cannot claim to apply sanctions in neutrality.

Thus, rationality is limited because it requires differentiated approaches to respond to the principle of satisfaction and maximization. This analysis focuses on the firm, the agents being in possession of acts that result from the observation of claims to obtain a profit. The individual does not have all the information and his or her calculation capacities, which makes maximization methods difficult in most real and anxious contexts. Success is the only way to reach an agreement with all members of the organization and to reach an authorization.

The work of Cyert and March (1963) is focused on the firm from an open angle on the measurement of internal management. Difficulties far removed from the simplicities of the black box are observed. It is Chandler's (1988) insight into the form of the modern firm that provides information on the driving force behind organizational structures, namely the repetitive change that sets the pace of the dynamic of progression. The following figure leads us to identify contractual approaches in a context where the firm is 
understood as a set of relationships, with a contractual criterion, that is, a "knot of contracts" between individual economic agents.

\section{Firms Theories}

The industrial fims theories treat about governance problematics reinforcing management perspectives.

\section{THE POSITIONING OF THE FIRM'S THEORIES}

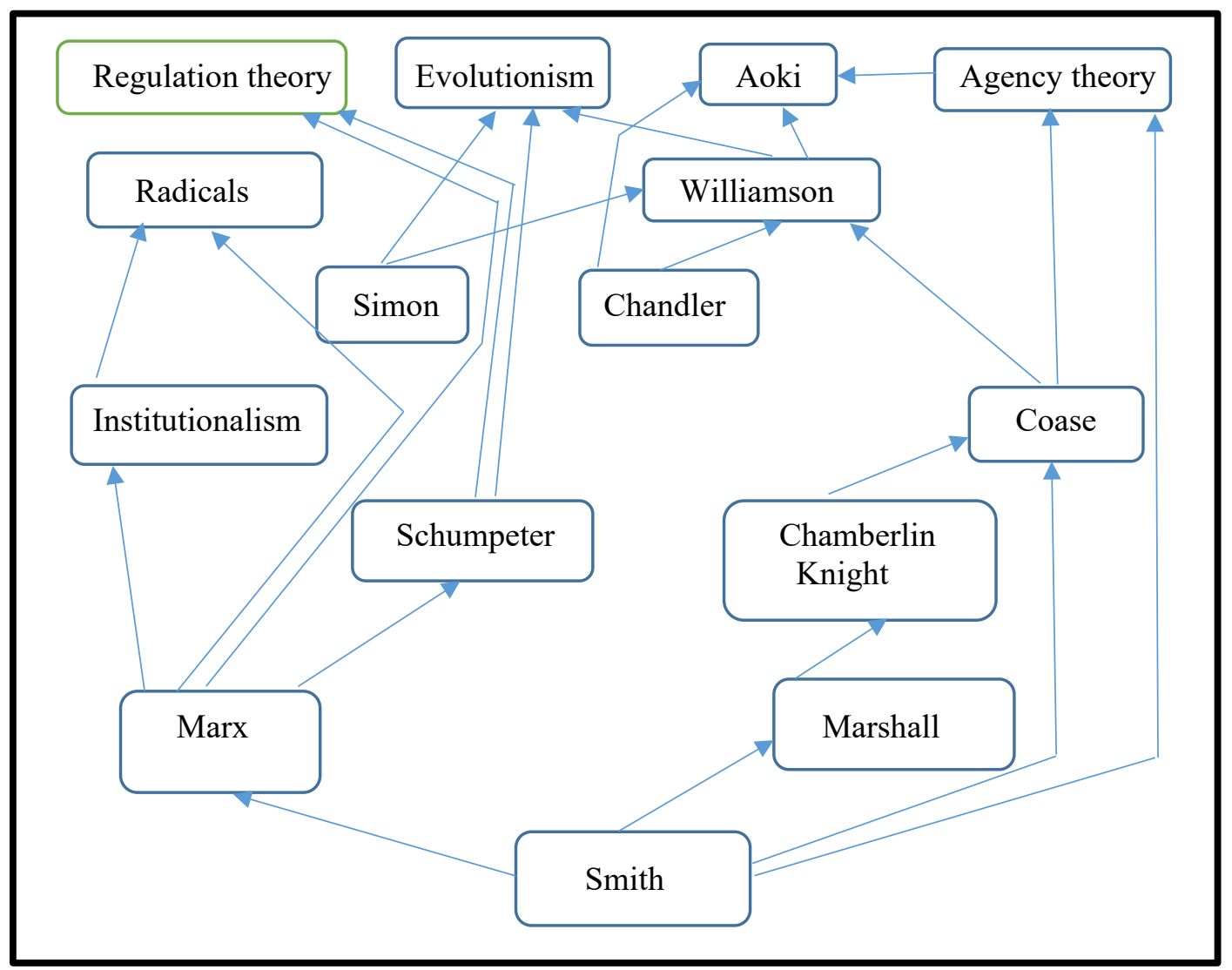

We can argue from the underlined figure, that the agency theory, that of Williamson and Aoki are placed as theories focused on the problem of contractualization. However, they emerged long after Coase (1937) had questioned the reasons for the survival of the firm. When the market is considered an important aspect of the link between activities and allocations, why make a separation between "market" on the one hand and "organization" on the other? The transaction cost approach sheds light on this question.

Thus, agency theory is at the heart of modern neo-classical approaches. It takes up the theory of the firm on a foundation that absolutely conceives of the virtues of methodological individualism and the foundations of behaviour revealed by Adam Smith (1776). Aoki, continues her work on Japanese firms, while revising the concepts of agency theory and Williamson's theory of transactions costs by examining Chandler. A new organizational structure of the firm is determined.

The figure also presents the evolutionary current focusing primarily on change. This current is in line with Marx and Schumpeter's analyses of the centralized location of operations and Simon's (1993) analysis of wealth creation and innovation. Organizations are people-centered workforce principles and groups whose predominance informs different interests and ideas. Organizational theories detail the complexities of conflict in agreement, resource mobilization, and planning for conflict that arrange for the mutual survival of an organization and its members. 
The organization is a place for managing conflict and interests. The employees are accredited by the "firm institution". This vision allows a social, legal and political recognition which is centrally introduced on the conveniences of property rights where the styles of relations between credit and industry institutions, the means of financing and more exactly all the laws, arrangements and sanction procedures historically designed to found the styles of relations between people.

\section{ON SHAREHOLDER GOVERNANCE}

\section{The Emergence of Managers}

The shareholders and managers within the company form a family team. However, their functions as managers and shareholders are different. When the growth is patrimonial, the entrepreneur's patrimony is expanding, and the family capital dynamic is struggling with financial constraints. As the development of businesses generates more and more funds, capital ownership and auditing remain two separate roles that lead to financial growth. As a result, the principal will not necessarily be a manager and the latter will not necessarily be a relative.

The cohesion of objectives is not defended between the owners and the managers. Disagreements or conflicts of interest are numerous. They generate costs. The main shareholders are more in favor of maximizing value, despite the risk they incur, while the executives earn a better reward, in terms of compensation, power and prestige. When the management of the company is independent, the shareholders develop a new concept of the structure of decision verification, but also for the attitudes of the managers, the links are characterized in a contractual form.

Jensen and Meckling (1976) define the agency relationship as "a contract by which one or more persons, the principal engages another person, the agent, to perform on his behalf a task involving delegation of decision and giving authority to the latter". This agency relationship constitutes the hub of the company by distributing tasks. The shareholders play the role of verification while the officers have a decision-making role.

Fama and Jensen (1983) capture the emergence of managers based on three functions, namely, the assumption of residual risks, management and control. However, the risk in managerial companies remains fairly high, according to (Hawley and Williams, 2000). In fact, the manager is always looking for a managerial rent, which is a sort of liquidity reserve for future opportunities. His wait-and-see attitude may lead him to build it up by means of allowances or privileges in kind. For the shareholder, this approach represents a great risk of hiring a manager without acknowledging his competence. Agency theory suggests that the actors (principal and agent) maximize their utility function. Opportunistic behaviors will arise in the middle of the different relationships.

Given the duty of managers, maximizing shareholder wealth in the short or long term leads to the creation of shareholder value. When capital is scattered and gives too many opportunities to managers, conflicts arise, because the firm is a knot of contracts through which shareholders and managers come together (Jensen and Meckling) (1976).

"The arrangement of the control mechanisms will have to solve the complications between the agent and the principal" (Jensen and Meckling) (1976), Fama, (1980), Fama and Jensen (1983). According to Shleifer and Vishny (1997), the structure of shareholder governance favours ensuring the profitability of financial investment.

Thus, the manager is not rewarded at its fair value, for his or her persistence, for the growth and development of the company, which brings benefits to the shareholders. Raviv and Harris (1991) point out that "agency conflicts arise from the dissatisfaction of managers who cannot benefit from the gains". As a result, managers will behave dishonestly in order to benefit from advantageous favors. If shareholders decide to allocate a portion of the shares to managers, the managers will have a completely different interest.

By putting in place the principle of employee shareholding, shareholders hope that the manager's interests can converge with their own, and that this principle can have a positive impact on the company's performance. The objective of this means is above all to make their interests converge and also to reduce agency expenses. The convergence of the objectives of the managers and those of the owners could be the 
subject of observations between external shareholders and employee shareholders. Autenne (2005) explains that employee shareholding is seen as an incentive contract aimed at impacting the attitude of employees towards the creation of shareholder value, more precisely, it aims to align the interests of employees with those of shareholders (Long) (1980), (Desbrières) (1989), (Blubaugh) (2002). (Garfatta) (2010) expresses the same order of analysis. The solution of aligning the interests of employees with those of the shareholder would make it possible to see employees invested with the sole aim of maximizing shareholder value. In this context, they would be more reactive and more disciplined about wealth creation, because they are considered as a principal who must maximize his own utility function. Hollandts (2007) determines that the meaning of the relationship is not important since the objective is global, both for the firm that will create value and for the shareholders who are the residual creditors.

Another advantage of employee share ownership is the fact that it enables close relations between the shareholder and the employees to convert their convergence into a single interest. Hollandts (2007) considers that the granting of shares and ownership rights towards employees creates inefficiencies at three levels, within the context of three types of agency relationships: between employee shareholders and employees; between employee shareholders and external shareholders; and between employee shareholders and management. The upheavals of divergent interests could lead to an increase in opportunistic attitudes of employee-shareholders. Indeed, the fact that they are principal and employee shareholders enables them to obtain essential information that they might not disclose to shareholders but also to managers to favor their portfolio. The relationship between employee-shareholders and managers must be monitored. Indeed, the employee shareholders will set up a monitoring system for managers. This method guarantees them that the management of the company and the interests of the shareholders are in good hands. The parameter of verification joins the problems of power but also of the importance of employee shareholding on the maneuvers of power in a company.

\section{Employee Ownership}

Agency theory focuses on questions related to incentive and control in the firm. This scientific circle is often solicited for analyses on the means of employee remuneration. Possessing then a good approach, the criteria from another angle of analysis, considered employee shareholding as a model of remuneration recorded in the long term.

Indeed, the increase in performance-based compensation methods is compatible with agency theory. Several species of motivational pay are identified: behaviour with intensive monitoring and performance.

Behaviour-based arrangements focus on controlling employee maneuvers. They require a higher level of supervision, organization and also support from shareholders. Such a control system is appropriate when the production process (input and output) is well understood and there is no credible measurement of individual results. In addition, agreements based on the performance achieved may be better when work systems are not well understood and reliable means of results exist. Such performance-based agreements will at least require management control. Since the production system is increasingly difficult for the firm, this would represent a major expense for supervision, moreover, whether they are accompanied by remuneration systems such as profit-sharing, employee profit-sharing or employee ownership of the firm's shares.

As from 1999, we can focus our attention on the performance-based compensation process. It is a solid method of selection as well as socialization. All employees behave in an irreproachable manner to achieve the company's objectives while relying on the performance culture. Similarly, a collective compensation process is based on performance. In addition, this can be subject to reciprocal control, on its attitude and the operation of colleagues by the employees. They will want to be certified themselves that no one deviates from the common goal. The authors made many arguments. Judgement of influence based on collective agreements may be more effective than the influence of individual agreements. For the complexity of estimating the individual share, they argue that groups of employees are much more informed about their individual prowess than management.

For this reason, collective influences advise group members to inspect each other, motivate and encourage each employee to work hard and behave properly. Depending on the arguments given, employees 
may even be led to help each other by performing several services for each other. This will mean that there is a good cohesion within the group in order to protect each other. Collective influences can help such practices, and the ability to reject support for a shirker. It can be effective in getting all members of the group to adhere to the collective norms of the group.

So, we have to emphasize that employee ownership more easily aligns the interests of employees with those of shareholders. Agreement is judged by the atmosphere, understanding, cooperation of employees and management, but also the growth of mutual verification. The quality of work, but also the flow of information within the company should be more perfectible. The employees should have a better organization of their work, and in addition, they will have to report information to the management and to their colleagues by means of communiqués. In addition, they should also be involved in the training of new employees.

Various questions treat about the presence of employee shareholding that would be beneficial for employees. It would even be an example to follow for acquiring new skills but also for longevity within the company, which reduces costs related to turnover. Nevertheless, one must point out the lack of consensus among the authors who have analyzed the importance of employee ownership through the prism of agency theory. Indeed, part of the literature indicates that employee ownership could lead to a rooting. This can be done by managers in the firm, by minimizing the efficiency of managers' control mechanisms.

We can to point out that "employee share ownership, which owns part of the capital, is seen as a friendly fraction of the capital". In the event that employees commit their human capital to the firm, they will be seen as principals in the agency relationship.

Now, they must ensure that the conduct of managers does not harm them. This could lead to a reduction in the value of their human capital. This anxiety of employees influences them to actively control managers. The latter are attached to the titles of property rights, mainly through their perception in the firm's governance system.

\section{The Complexity of Theory Versus Context}

An organization is permanently confronted with an attempt by its leaders to take control of the organizational rent. The power of the leader is to valorize his utility function through investments. It also means benefiting from essential information without disclosing it to shareholders, but still being in a position of strength by asserting his power a little more, making his replacement costly. For all these reasons, managing it is of paramount importance in the company's activity.

In order to restrict all the manager's wait-and-see behavior, the shareholders will put in place control protocols. These will be mechanisms envisaged in agency theory. Transaction cost theory suggests a protocol by a spontaneous or intentional character. The consequences of such acts may weaken the firm in terms of competitiveness, and it is in relation to this risk that Demsetz (1983) thinks that the manager should restrict mistic deductions. Agents may be dismissed at any time by the board of directors. They will then be looking for offers in this market. Thus, the manager may see his or her reputation damaged in the market because of their opportunism. The paradigm of Fama (1980), notes that the human resources estimate of the agents' human resources can be measured by the basis of authenticated previous achievements for the firms in which the manager works. The influence of the labour market on managers is aimed at pushing managers to be efficient, and there is no assurance that the available statements of managerial ability are accurate.

Just because an executive has a good reputation and success in other firms does not mean that he or she can do so at the head of every firm. The labour market performance of executives concerns only a portion of the firms in countries where there are arrangements between executives and directors. In such circumstances, the labor market is presented as being compartmentalized, because there are mechanisms to protect managers from a market diagnosis.

Governance methods are prepared to regulate the manager and improve selections, as well as to caution financial investors of their optimal shareholder value by being able to restrict agency spending. Agency cost is the basic component that drives the need to align the interests of the executive with those of the shareholders. 


\section{Failing Governance and Questioning}

The link between agents and owners remains the basis for understanding the status of the manager. The origins of agency theory show that the agent who is not an owner is an additional expense. However, the manager and the shareholder have roles of primary necessity for the firm, even though their functions are different from their interests. The central element for the realization of wealth is the selection of investment projects. The manager has nothing to do with this.

The core of Jensen and Meckling's (1976) theory emphasizes efficiency, which is, moreover, much better than the objectives of the agents granted to the owners. The place of governance methods is the restriction of agency spending, linked to problems of intention between principal and agent. If the divergence of interests of the principal is closer to that of the shareholder, then the company will be more competitive. According to this approach, the role of governance methods is to reduce the managerial attitude to the level of several methods that constitute it, whether intentional or spontaneous. Adams and al. (2005) assert the importance of agents in performance. The latter holds a privileged place at the heart of the value creation system. His managerial methods are dynamic, lively (Breton and Schatt) (2003), Galai and Masulis, (1976), and denote several appearances: distinct qualifications, personal aspects.

- The agent develops distinct adaptation with an original and special attitude in projects and also in decision making.

- The agent has power within the company and is at the heart of the competitive game. He realizes exchanges of income of the different collaborators with the owners.

- The agent has the ability to restrict profits to refrain from discussions with employees or unions (Waterhouse and al.) (1993). This easily calls for measures such as layoffs, plant closures at the expense of employees. It may be able to constitute a false financial circumstance for which the risk of discomfort is low in order to benefit from a resource at a reduced expense and avoid a reduction in assets.

Under this axis, shareholder governance mechanisms aggravate the hazards of several other stakeholders, that's to say all those who are not owners.

Corporate finance and microeconomic theory (Stewart) (1994), (Caby and Hirigoyen) (1998), indicate that the primary financial objective is the maximization of shareholder wealth. The aim is to be able to guarantee all types of revenue without necessarily managing the development of the business. This approach neglects partners as well as employees. In addition, contractual shortcomings remind us of the poor condition of the foundations of the theory of the firm about general equilibrium. It makes no sense to have an agreement on all contractual relationships.

Production management can solve the problem of imperfect agreements by giving the owner all residual rights of control and application of assets within the firm. The implementation of mechanisms observes the wait-and-see behavior of managers. The design of the agency is appropriate to this imperfection according to Grossman and Hart (1986). The component of this composition of the agency relationship allows the owner to be the only residual creditor, but also the only one who can take on the threats of a residual risk. Many authors believe that this perspective is monistic, as it favours a provisional and limited period. They then suggest a repetitive perspective to satisfy several parties. Garvey and Swan (1994), question the fact that corporate governance cannot be accepted in a world where property rights are programmed and the only beneficiaries of wealth creation are shareholders through their rights as creditors. It is mainly when the contractual formalities are incomplete that governance problems arise, with the result that shareholders no longer possess the real residual creditors (Garfatta) (2010). The improprieties to the conditions of shareholder value are of several orders (Albouy) (1999):

- The complication of the estimate is that the means cause several accounting restatements.

- The threat of the short-termists directly or indirectly at the heart of the accounting and financial statements made by the markets and the accounting intelligence processes.

The gratitude of shareholders is increasingly problematic. Listed companies are good examples. Shareholders are not the residual decision-makers, but they are also not the only residual creditors. They will not be the exclusive owners of property rights (Charreaux) (1997). In corporate finance, the element 
of value maximization has been considered as an option to the traditional philosophy of profit maximization. Nevertheless, the value field had a conformity. This way of doing things has evolved over time because nowadays the firm is considered more like a partnership firm (Hirigoyen) (1997).

\section{PARTNERSHIP GOVERNANCE}

The approach of the parties in an organization fits into a classical context.

\section{Stakeholder Theory}

A Stakeholder theory requires a scientific explanation of the existence of stakeholders. Andriof and Waddock (2002) put forward two reasons: legitimacy and power. People who make a contribution to the firm or have a right over it have a certain legitimacy Evan and Freeman (1988). Legitimacy is given to those whose happiness formally depends on the firm or who have a legal or moral right to the firm, Langtry (1994) argues. Suchman (1995) defines legitimacy “as a generalized idea or assumption that a firm's securities are desirable within a social system of norms, values, and beliefs". This work demonstrates that law does not appear to be exclusive to owners (Garfatta) (2010).

The legitimization of Stakeholder's theory is rooted in the conception of neoinstitutionalism, which wants to discover firms, and to know them beyond their profit maximizing attitude. In this conception Stakeholders discover a multitude of explanations and foundations. The neo-institutionalist works previously expose the need for an organizational firm to abdicate the external normative impulse (Gond and Mercier) (2005).

Another explanation results from power, which is part of a strategic coherence. The nature of the stakeholders must be explained by the nature of the links of power and therefore of mutual dependence among the company and several teams that make up its explicit atmosphere (Andriof and Waddock, 2002). Many analyst-practitioners have tried to install control in the company. Actors are defined as those who have an interest in a firm's securities and can have the strength to influence it (Savage and al., 1991).

Control can be seen in the sense of having the ability to influence stakeholders mutually. Constructions are varied such as the Starik (1994) contract node (Jones, 1995), transaction costs (Preston, 1995) or agency theory (Hill, 1992 and Judith, 2003). This is a classic conception of the firm. Each manager must respond to the interests of the principal, that is to say create value for shareholders. The company's obligation is to provide a sound guarantee for the various parties. Already Ansoff (1968) emphasizes that "the firm must review its objectives so that each partner can have a fair share of satisfaction". Therefore, the firm should instead harmonize all the partners' interests, namely, the managers, customers, employees and suppliers who are incompatible.

The broad stakeholder approach is given by Freeman (1984,) "a stakeholder is an individual or group of individuals who can impact or be impacted by the achievement of organizational objectives". Clarkson (1995) believes that one should not talk about stakeholders without inserting the dangerous elements. According to this method of organization, the realization of wealth should benefit from the participation of several partners. All of these stakeholders can be exposed to the economic dangers they face in society. The problem is to identify and distinguish the different stakeholders. Charreaux and Desbrières (1998,) considers that it is an agent whose usefulness is impacted by the firm's choices.

According to Clarkson (1995), there are two opposing classes of partners: primary partners and secondary partners, who determine two types of stakeholders, voluntary and involuntary Charreaux and Desbrières (1998).

Stakeholders who are voluntary will be exposed to danger by investing, while involuntary stakeholders will be exposed to the sanctions brought about by the company's activity.

Carroll and Näsi (1997) compare internal stakeholders, that's to say owners, managers and employees with external stakeholders who are competitors, consumers and others.

Mitchell, Agle and Wood (1997) identify a third attribute of Stakeholders. Henceforth, urgency will be added to the attributes of legitimacy and power. Urgency is defined as the extent to which the rights of Stakeholders need immediate attention. 
FIGURE 2

STAKEHOLDERS IN THE COMPANY

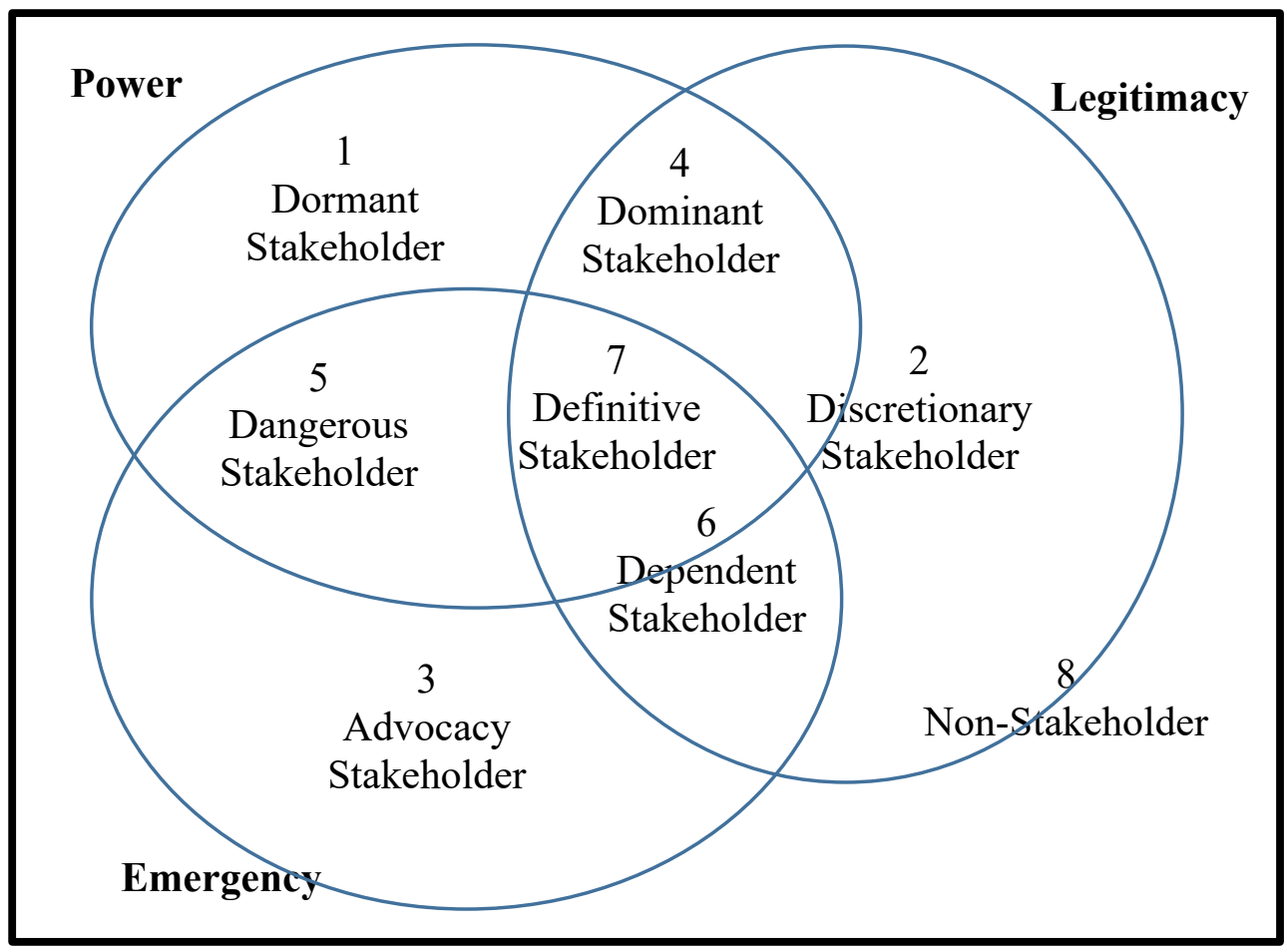

Source: Mitchell, Agle, and Wood, (1997).

According to Figure 2, members in zones (1), (2) and (3) possess only one character, namely legitimacy, power and urgency. Managers have not been overly concerned about these stakeholders. Partners in region (4) possess two attributes at the same time. These are legitimacy and power. These stakeholders are very imposing and very important. Their solicitations will hardly pose an alarming danger to managers. Concerning the region (5), the partners have two attributes, power and urgency. Managers are often assimilated to this type of stakeholder. Attentive managers may exaggerate their power to influence the intentions of stakeholders who represent a certain legitimacy. Zone (6) is the complete opposite of zone (4). Stakeholders are stifled and submissive because they have no control over the enterprise. They have two attributes: legitimacy and urgency. In this type of stakeholder, shareholders and employees can be led to the extent that there are absences of defense associations, and absences of powerful trade unions. Zone (7) is the sum of the three attributes: legitimacy, urgency and power. All the more so as their demand remains urgent in the eyes of the leaders. These stakeholders certainly concern alliances between the dominant members within the company. Finally, the region (8) refers to stakeholders who do not possess any characteristics. They are not judged as partners.

To close this section, we will retain the implicit and explicit recognition marking two distinctions of the stakeholders. It refers to informal or contractualized relationships Fiore, Grand and Suzanne (2008).

\section{An Analysis of the Nature of Partnership Governance}

We refer to Donaldson and Preston (1995) on applications of stakeholder theory, namely: Descriptive, instrumental, normative.

The descriptive dimension of the theory is determined by a representation of the links between firms and their environment. It explains the way in which the interests of the stakeholders are accepted, which leads to explain the characteristic of the company: How can organizational decisions overwhelm employees? According to (Moore, 1999), the firm is conceived as a constellation of cooperative and 
competitive interests. It is programmed in such a way as to resolve the difficulties of increasing the number of new organizations as well as the questions impacting the organizations on their circle and society.

For the pragmatic aspect, the stakeholders that would not be mainly, considered as elements allowing the enterprise to reach its interests, demonstrate that the agents do not fulfill their duties. The manager must have a good grasp of the stakeholder theory, because it will enable him/her to properly conceive the vision of things in order to have a better management. In fact, the theory is seen as an improved theory of agency theory. This improvement considers approaches to power, reward, and the ethical implications of stakeholder relationships.

The normative aspect refers to the work of Freeman (1984). It is an option conception of strategic management where every stakeholder is entitled to attention. Increasing profit is a problem because of the need for legitimacy. According to Freeman and Evan (1988), gratitude for their objectives requires that stakeholders be integrated into organizational decision-making systems. Therefore, the enterprise is a method of satisfying the needs of several stakeholders (Freeman) (2000). This organization will have broader vocations than a simple increase in income, contrary to the shareholder vision. The normative stakeholder theory is also based on other ideas such as those of the social contract theory stated by Donaldson (1982) and Donaldson \& Dunfee (1994).

This conception is based on the fact that moral rights take part in the growth of the firm's well-being. It responds to all stakeholders in the rules of law without violation. The work of Husted and Etzioni (1998) takes into account, on the one hand, the normative grandeur based on works of organizational justice, and on the other hand, the fact that shareholders are not the only ones to make decisions. All the actors who invest within the firm, whether through financial investment or human capital, benefit from the interests.

We recall that stakeholder theory needs managers to take into account the fact that a firm's performance is also determined by the attention they pay to the interests of the parties. Donaldson and Preston (1995) point out a similarity of approaches centred on their managerial characteristic.

The descriptive, instrumental and normative dimensions can be divided, but the normative dimension will always be at the center of stakeholder theory, a view shared by Carroll and Buchholtz (2000), who consider that improving ways of governing should not be the only anguish of the parties, but an ethical method of governance. Jones and Wicks (1999) follow the same line by presenting an agreement between the dimensions of the instrumental and normative branches of stakeholder theory.

\section{The Creation of Value}

The company is considered as a group of exploitation where the birth of the profit is handed over by the different associations that end up in a single manufacture. In this theory, there is no question of a residual creditor only for the shareholders, hence the questions about the distribution of organizational profitability. The other elements of the operation will only be captivated to participate in the creation of value if they receive part of the rent, thus acceding to the status of residual creditor (Charreaux) (2002). This conception finds its originality in the incomplete contractual principle : ownership is determined as much by the remaining decision-making rights as by the receipt of the remaining income. It is then feasible to extend the rules of ownership to all participants in the node of productive contracts.

The business relationship and the stakeholders are not naturally in agreement. They are designed to create partnership value. Charreaux and Desbrières (1998) define firm relationships as the distinction between total revenues valued at opportunity prices and the opportunity prices of other production elements.

To the creation of a governance framed on the relationship between the owner and the agent, it corresponds to a more difficult governance, abandoning places to market regulatory methods and favouring more institutional methods, giving more importance to several relationships linking several partners. Stock markets have a minor involvement compared to the major involvement of credit institutions in the financing process and the control of firms. This partnership method is based on internal coherence led by networks. It enhances value creation for all partners, that's to say customers, suppliers, employees and shareholders.

According to Freeman, (1984) when stakeholders achieve their objectives, financial performance increases. Jones, (2001) develops the same analysis by pointing out that when the firm manages to obtain an excellent relationship with stakeholders, it is able to generate value for companies with an odious 
relationship. The firm will benefit from more prolific resource flows by virtue of its relationships. This kind of governance benefits the amplification of financial capital and human capital in terms of (know-how, skills, innovation). Charreaux, (2007) insists on a pooling of capital, the role of public power, the existence of the tough origin of shareholders, the weak appeal to financial markets, a reduced market capitalization and an amplified labour law. In this context, the firm is a node of contract. It is impacted by several levers of the various stakeholders. The contractual relationship implies a double risk: the informational risk and the agency risk. The management of these risks requires influencing factors that call into question the form of the partnership value.

The partnership disciplinary form comes from the illustration of the firm as a team of operating elements, whose associations derive from organizational rent. The composition of the estimation of partnership forms leads mainly to the resolution of conflicts of interest concerning the distribution of this value. The questioning of the origin of the rent leads to its being brought to light. In addition to managerial capital, there is that of human capital to be taken into account, which corresponds to the particular knowhow of Blair $(1995,1999)$. When the character of this capital is derived from the annuity, it also expresses the fragility for anyone who will have the initiative in attempts at dispossession. Brandenburger and Stuart (1996) explain that the value created is the entire organizational rent produced by the firm across all the value chains designed by the various partners (Porter, 1985). The attention of the assortment of partners in the value chain leads to name this partnership value rent as opposed to the one that constitutes the attribution to shareholders only Charreaux and Desbrières (1998). In this reproduction, the means of remuneration and the rise in risk have a crucial place in appropriation. Conversely to the shareholder value framework discussed earlier, where the totality of the rest would go to the principal shareholders, partnership value leads to the problem of its accommodation for several employees. The danger endured by all the stakeholders involved in the contractual relationship is that both impact and control play a key role in appropriation.

\section{Conflicts Between Shareholders and Stakeholders}

Companies have a lot of means for a coherent dialogue within the company, for all its collaborators. The culture of the organization is based on the strategies incorporated in the organization. It is also based on the modes of communication with its partners, stating the consequences but also the benefits. Communication remains the basis of the good functioning, there must be no asymmetry of information between partners. The meetings are a method to make converge, exchange ideas and interests of all with the aim of obtaining a unanimous decision for the company.

Societal reporting is an indicator that is beginning to have its place within companies, unlike financial reporting. It is an organizational method for steering strategies that is developed during governance bodies, the latter being responsible for monitoring the consideration of social commitments, so that they are in line with the expectations of all partners. In this way, we can approach conflicts from a variety of models.

\section{Aoki's Cooperative Model}

According to Aoki, there should be no conflicts between shareholders and stakeholders if both parties would cooperate. When shareholders and stakeholders converge on a cooperative game in terms of revenues, then each party will get its interests. During the negotiation meetings to reach an agreement, each party would not want to leave any ballast to diminish its objectives. When distributing the organizational rent, the benefits will have to be shared, according to the methods decided upon beforehand, so that each stakeholder can obtain his or her rent interest. When one of the actors has no interest in cooperating, it will then provoke a deterioration in the distribution of gains and, subsequently, conflicts. For conflicts to be avoided, all the parties must be involved and negotiations concerning interests must be addressed as soon as the contract is signed. 


\section{The Perroux Model}

François Perroux (1961) questions the fact that problems cannot be solved without social dialogue. The latter is achieved in the joint search, through contradictory communications, for a proposal judged to be true or a solution judged to be fair by two interlocutors who accept compatible criteria of truth and justice.

By choosing the concept of corporate social responsibility, the objective is to develop a strategy of dialogue between all the partners rather than to solicit the importance of the actors. The assessment of the social responsibility of the company can be determined according to the availability of the willingness that all parties will give to the exchanges on their debate and their understanding.

The approach to corporate social responsibility is presented as a participative democracy, of a discussed economy. It seeks to ensure that each stakeholder is not disadvantaged in relation to another. It is necessary to find the right adjustment to have a good harmonization within the company.

Another aspect of performance is revealed in the method for estimating it. For a long time, the financial indicator has been the basis of the evaluation. From the 1990s onwards, other non-financial indicators are taken into account. Thus, as Perroux (1957) points out, firms are certainly machines for producing externalities, but they have learned to exhibit their strategies and values to the various partners. The application of communication methods should be used in all firms.

\section{Savall's Socio-Economic Model}

This model mentions that corporate social responsibility has become longer in relation to the rise of stakeholders. These increases are mainly due to the lack of social communication. The consequences of a lack of social dialogue can generate costs that will have to be borne by all partners but also by the company. These costs arise from conflicts with respect to the steering indicators that will have a transparency on responsibility (Henri Savall) (2009).

The management model (Henri Savall) (2003) is based on a socio-economic approach to organizations that constitutes economic and social variables. Certain elements are always present regardless of the organizational structure, but also the attitude of employees. These elements behave positively and negatively for the company, which has the ability to be a driving force for exploitation and a source of conflict of interest. Difficulties cause hidden costs that correspond to a loss of value. This is why it remains important to find the right balance between economic and social performance, the latter being in charge of having control to reduce hidden costs and satisfy stakeholders so that all partners are performing well.

\section{CORPORATE GOVERNANCE IN FRENCH GUYANA}

On the basis of the theoretical teachings, we proceeded to a sample selection covering 22 companies that agreed to submit to our questionnaire. They were drawn from a large sample based on size criteria representative of the economy of French Guyana.

\section{Representative Criteria}

INSEE (2020) lists 14,974 companies representative of the Guyanese economy. More than $80 \%$ of the companies are located in the territory called Cayenne Island, whose capital benefits from tax breaks depending on the zones, including urban areas. This fact is a strong influence factor for their establishment. The cities of Matoury and Remire-Montjoly which are part of this territory are very well represented.

We note that the flow of Guyanese companies spreads rather on the coast consisting of the cities of Kourou, territory of the space industry of satellite launches, the city of Saint-Laurent du Maroni, economic, industrial and commercial capital of the western territory bordering Suriname. During our survey, we contacted 22 companies located in the following cities: 11 in Cayenne, 4 in Matoury, 2 in Saint-Laurentdu-Maroni, 2 in Remire-Montjoly, 1 in Kourou, 1 in Sinnamary, 1 in Saint-Georges. 


\section{FIGURE 3}

\section{DISTRIBUTION OF COMPANIES IN FRENCH GUIANA}

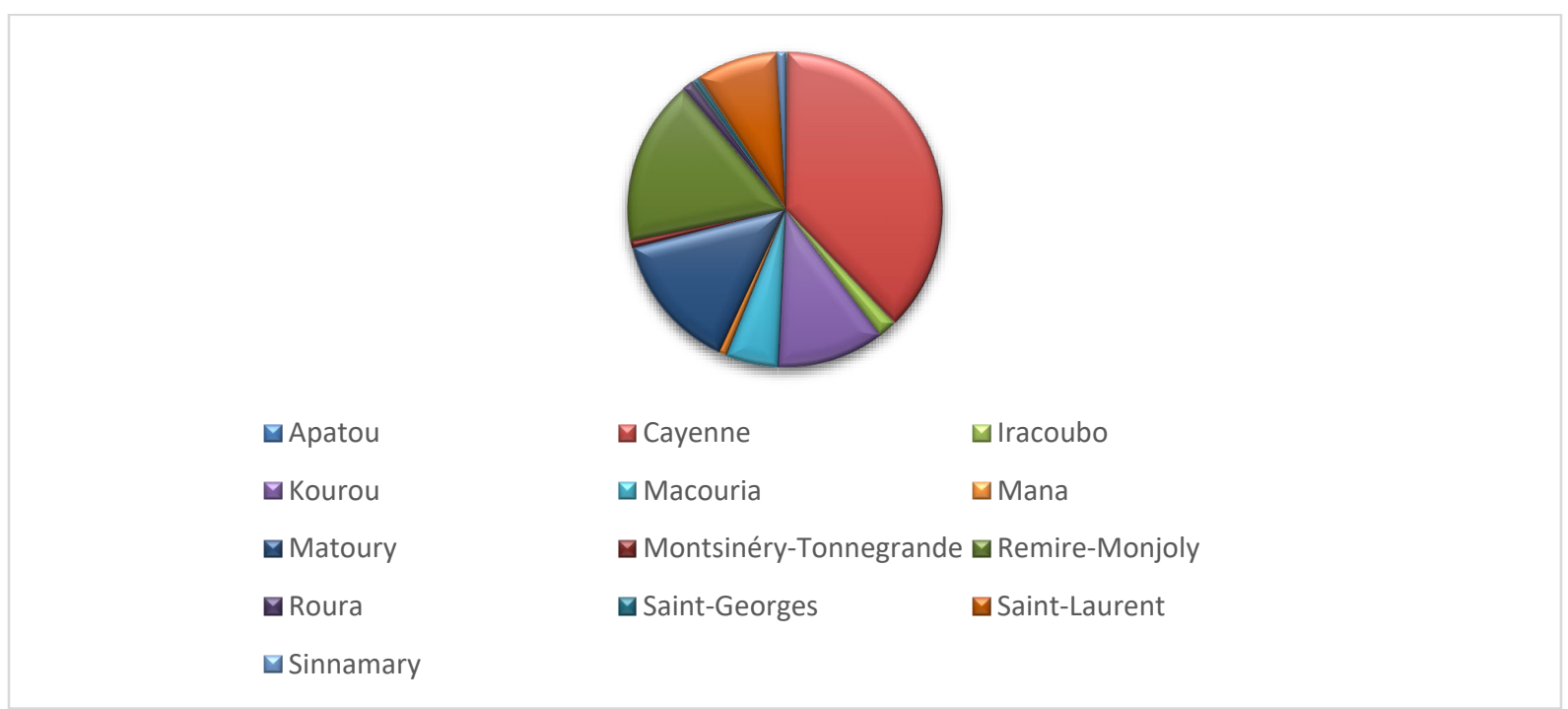

Source INSEE 2020

\section{FIGURE 4}

DISTRIBUTION OF COMPANIES IN FRENCH GUIANA BY SECTOR OF ACTIVITY

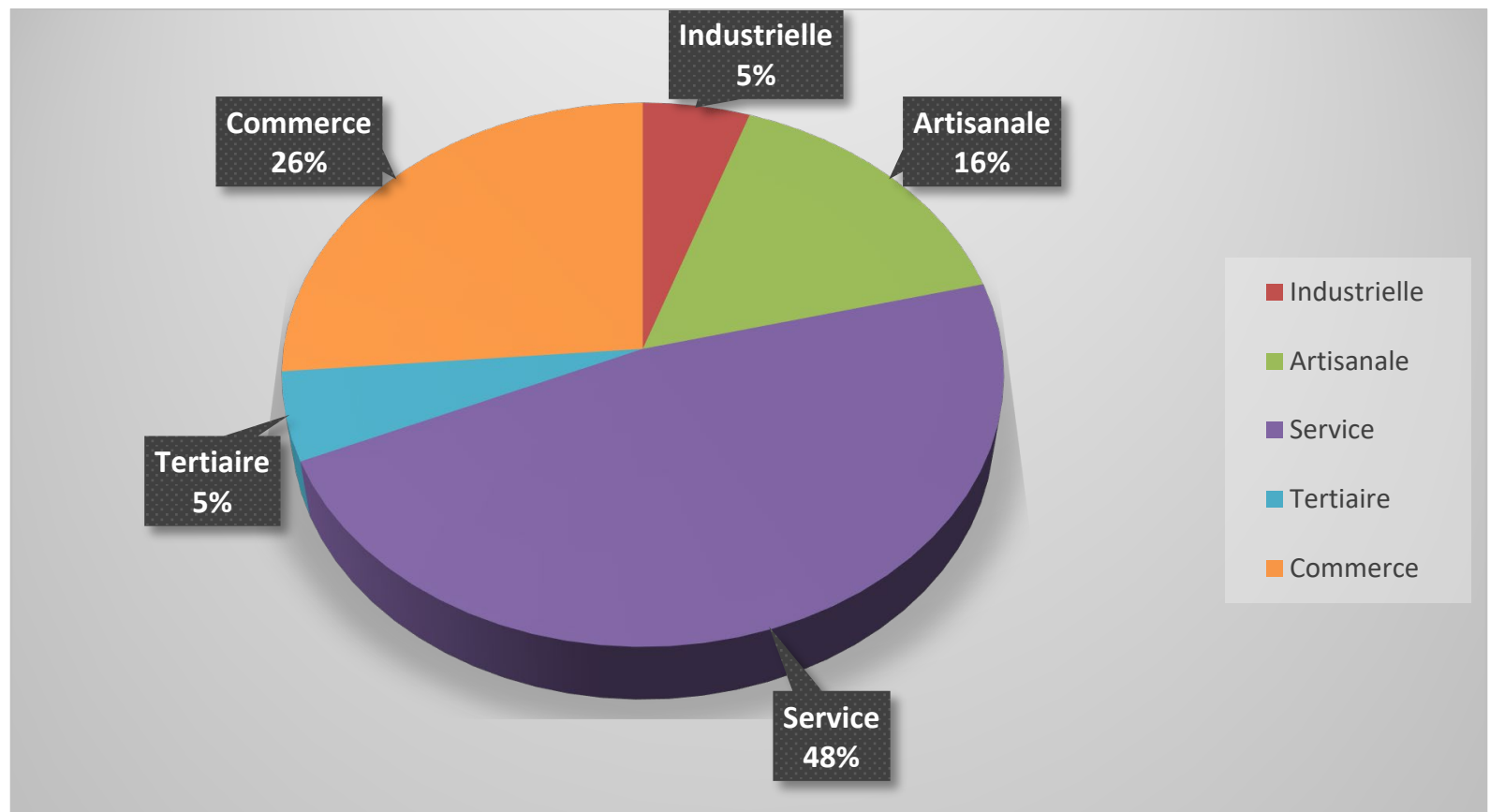

Source INSEE 2020 


\section{TABLE 1 \\ CATEGORY OF EMPLOYEES AND THEIR ACTIVITIES WITHIN THE ESTABLISHMENTS IN FRENCH GUIANA}

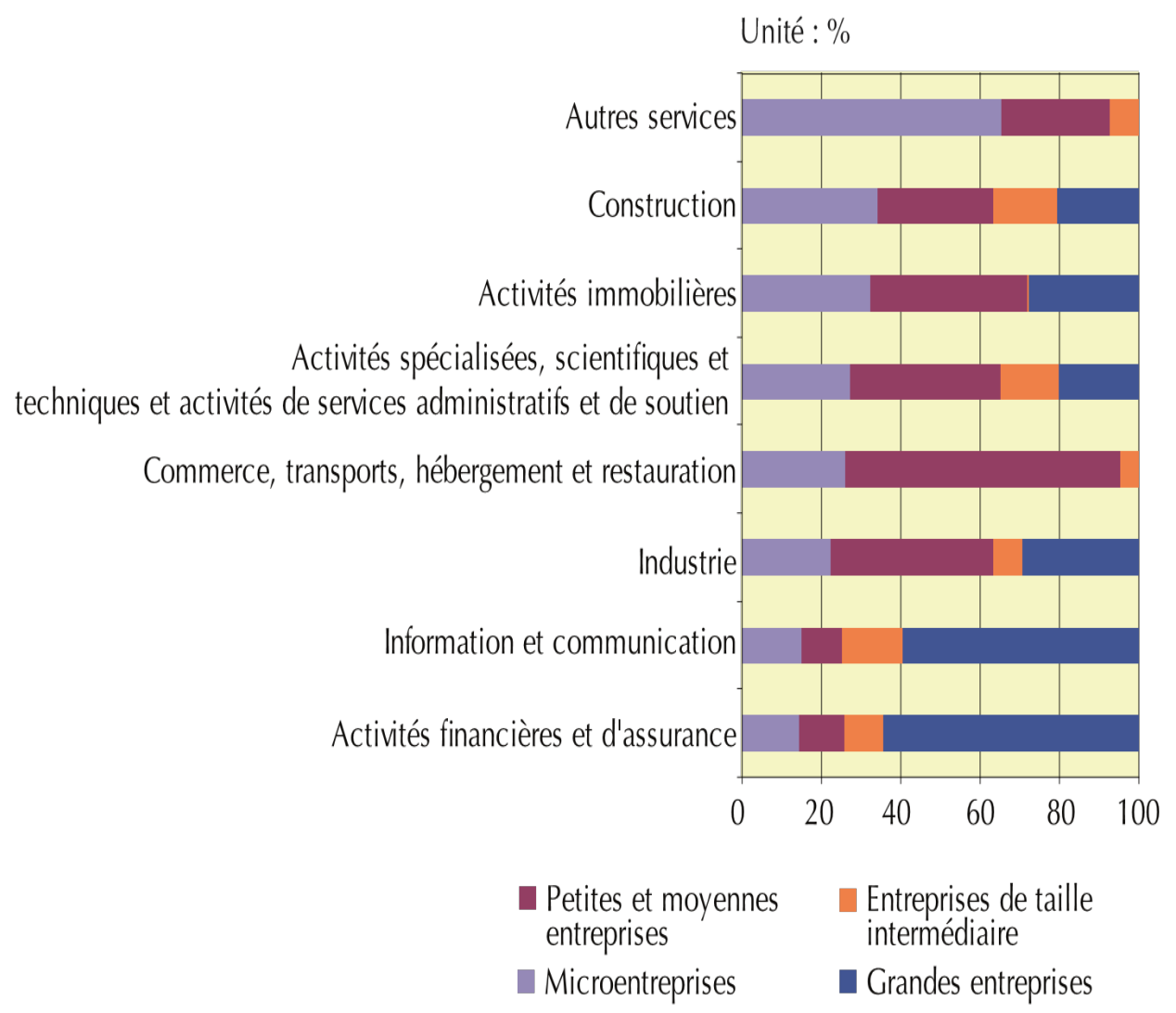

Figures 1 and 2 represent the spatial distribution of the economic, industrial and commercial activity of the companies selected for our surveys. Nearly $75 \%$ of the companies are located in the service, commercial and space sectors. This sample covers companies in different fields such as bakery, clothing, road transport, space industry, fishing, wood and gold. Our survey covered companies in the industrial and craft sector oriented towards the domestic market, but also those in the open space sector on the world market.

In French Guiana, most companies are SMEs and VSEs (Very Small Enterprises). Micro-enterprises are found more in the construction sector and in all other services such as after-sales service. SME-SMIs are representative in the trade sector (hotels, restaurants) but also in the industrial sector. The large companies will mostly be companies attached to the State like EDF (Electricité De France), the Postal Bank or to a consortium of global power such as ARIANE ESPACE, CSG. Among the 22 companies surveyed, the financial, insurance and communication sectors are growth companies: 15 very small companies, 6 small and medium-sized businesses, 1 large company.

\section{Methodology}

Our survey focuses on governance methods within companies in French Guyana. The aim is to assess the company's environment in the face of opportunistic employee behavior, conflict management, employee satisfaction and the distribution of organizational income. Other objectives include an understanding of the tools used to motivate employees to be more productive and knowledge of the employees' position when making decisions. The characteristics we have just identified can all have a positive or negative impact on company performance. It is therefore important to pay attention to them. 


\section{Method of Data Collection}

The choice is that of a quantitative study which consists in the use of several numerical data coming from the companies by the technique of a questionnaire. The latter is composed of

closed questions, multiple choice questions, open questions and scale questions to measure satisfaction. The duration of the interviews is determined by the exhaustion objectives of the questions.

The software used to compile the results is Drive Google Form. This software has been used to process a significant number of questions, taking care not to overload them to avoid the risk of a high dropout rate and a high loss of information, resulting in a low exhaustiveness result. The collection of all responses and processing is aimed at designing tables for analysis.

\section{Sampling}

TABLE 2

SAMPLING BY COMMUNE

\begin{tabular}{|l|l|}
\hline Municipalities Number & Number of companies in French Guiana \\
\hline Apatou & 37 \\
\hline Cayenne & 5000 \\
\hline Iracoubo & 333 \\
\hline Kourou & 1636 \\
\hline Macouria & 901 \\
\hline Mana & 149 \\
\hline Matoury & 2408 \\
\hline Montsinéry-Tonnegrande & 129 \\
\hline Remire-Montjoly & 2873 \\
\hline Roua & 205 \\
\hline Saint-Georges & 131 \\
\hline Saint-Laurent & 1431 \\
\hline Sinnamary & 141 \\
\hline Total & 14974 \\
\hline
\end{tabular}

Source Insee 2020

We use this table to calculate our sample. Our margin of error is $6 \%$.

Sample Calculation :

Let the following be the parameters :

$\mathrm{T}$ : the margin coefficient, $\mathrm{N}$ : the sample size, $\mathrm{X}$ : the margin of error

The sample $=\mathrm{T}^{\wedge} 2 * \mathrm{~N} / \mathrm{T}^{\wedge} 2+\mathrm{X}^{\wedge} 2 *(\mathrm{~N}-1)$

$$
\begin{aligned}
& =\left(\left(1,96^{\wedge} 2\right) *(14974)\right) /\left((1,96)+\left(0,06^{\wedge} 2\right) *(14974-1)\right) \\
& =1030
\end{aligned}
$$

The number of companies we should interview for our survey is 1030 companies. These companies must be chosen from all over the country to have a representative opinion. In the table below, the number of companies that we should question in the different cities of French Guyana is expressed in the 2nd column. However, in view of the COVID crisis, we are drawing up a representative sample of 22 companies 
where the island of Cayenne (Remire-Montjoly, Matoury, Cayenne) is the main area of investigation and the major coastal towns of Kourou and Saint-Laurent du Maroni, the second.

TABLE 3

SAMPLES OF TERRITORY

\begin{tabular}{|c|c|r|r|}
\hline \multirow{2}{*}{ Municipalities } & $\begin{array}{c}\text { Number of companies in } \\
\text { French Guiana }\end{array}$ & \multicolumn{2}{|c|}{ Percentage } \\
\hline Apatou & 37 & $0,2 \%$ & 3 \\
\hline Cayenne & 5000 & $33,4 \%$ & 344 \\
\hline Iracoubo & 333 & $2,2 \%$ & 23 \\
\hline Kourou & 1636 & $10,9 \%$ & 113 \\
\hline Macouria & 901 & $6,0 \%$ & 62 \\
\hline Mana & 149 & $1,0 \%$ & 10 \\
\hline Matoury & 2408 & $16,1 \%$ & 166 \\
\hline Montsinéry-Tonnegrande & 129 & $0,9 \%$ & 9 \\
\hline Remire-Montjoly & 2473 & $16,5 \%$ & 170 \\
\hline Roura & 205 & $1,4 \%$ & 14 \\
\hline Saint-Georges & 131 & $0,9 \%$ & 9 \\
\hline Saint-Laurent & 1431 & $9,6 \%$ & 98 \\
\hline Sinnamary & 141 & $0,9 \%$ & 10 \\
\hline Total & 14974 & $100 \%$ & 1030 \\
\hline
\end{tabular}

\section{Analysis of Results}

We select the most relevant results.

Conflict Management

\section{FIGURE 5}

\section{RATE OF CONFLICTS WITH COMPANY EMPLOYEES}

L'entreprise a-elle déjà été confronté à un conflit avec les salariés ?

22 réponses

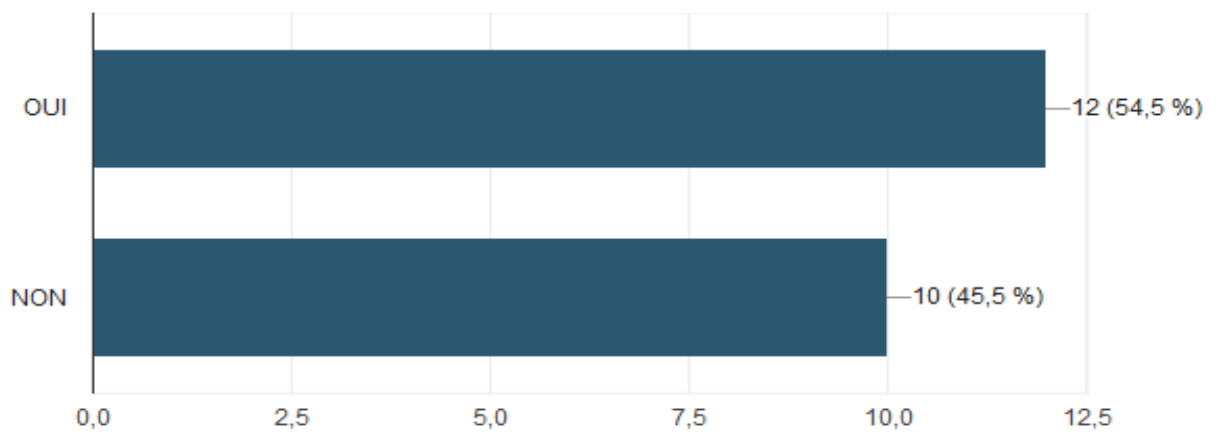

This result shows that companies in French Guiana are fairly divided on issues related to personnel. Indeed $54.5 \%$ of companies are faced with problems caused by various reasons. In the literature, we have mentioned that a company that is marked by conflicts with its employees has a strong impact on work 
performance. Indeed, the societal environment and the culture of the company do not suit the employees. This would be a source of problems. This conflict could become more influential if it involves several people to the extent that employees could go on strike. This would be harmful.

For companies that have never faced conflicts, this result represents $45.5 \%$. We can assume that management and internal communication with the management is going very well. This agreement develops the cohesion of a group whose mission is to achieve the objectives set by the company. An employee who has a good relationship with his company can evolve throughout his career within the company.

\section{FIGURE 6 \\ CAUSES OF CONFLICT}

Si oui quelle à été la cause de ce conflit?

11 réponses

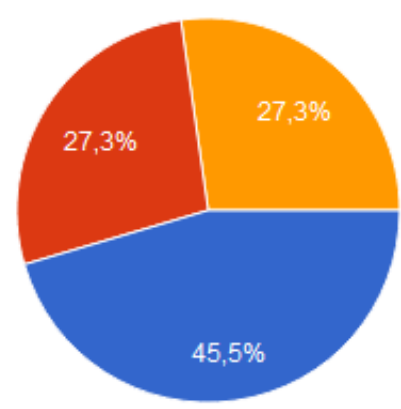
Mauvaise répartition de la rente
Mauvaise condition de travail
Autres

Among the companies facing conflicts, the causes are of three kinds, namely poor distribution of income, poor working conditions and others. They are very divergent. $45.5 \%$ of companies have conflicts related to profit distribution. This leads us to believe that for an employee, his interest is not equal to what he should have benefited from when his contract was negotiated. This is the case of a real estate agent who should receive a merit bonus for each sale.

The other cause of conflict is poor working conditions, which represents $27.3 \%$. It includes a whole set of elements of poor management within the company at several levels such as psychological, environmental, social and organizational. These levels determine the working atmosphere that the employee faces every day.

One in three companies is confronted with causes of conflict other than organizational rent distribution and poor working conditions. It may be a conflict of rivalry between two people in order to obtain better recognition from the company. Certain sectors of activity, such as commerce for example, can generate this type of conflict. It can also be a power struggle between fellow employees who encroach on each other's work area. 


\section{FIGURE 7 \\ METHODS OF CONFLICT RESOLUTION}

Quelles sont les méthodes utilisées pour résoudre les conflits au sein de l'entreprise?

22 réponses

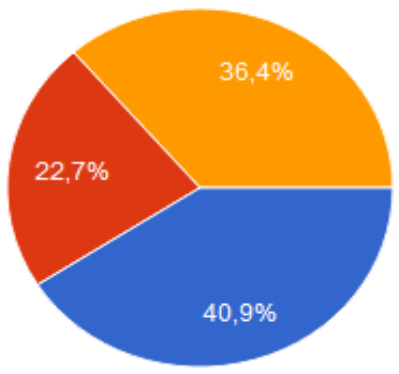

Dialogue social

Outil de managemnt

Jeu coopératif

Autres

The most widely used method is that of social dialogue. It is simple, quick and not expensive for the company. Unlike the cooperative game, there are no negotiations between the different parties. It is rather a communication. The aim is to ease the tensions of each one and to find optimal solutions for the interest of the company so that there is no discrimination at work.

The second most commonly used method is cooperative play. It is the most dominant method for resolving conflicts. In fact, $40 \%$ of the companies involved use it. This method allows all parties to agree on their objectives during meetings. This method of resolution must concern all the employees, in order not to cause a degradation of the separation of the latter and generate a management response.

Finally, the method that is least used is the one that puts forward managerial tools to solve problems. These tools can be very varied and hierarchical. For example, it is very likely that the employer will give his final decision on the conflict in order to end it quickly. This is a strategy to achieve a way out of the crisis or the end of the conflict.

\section{FIGURE 8 EMPLOYEE MOTIVATION}

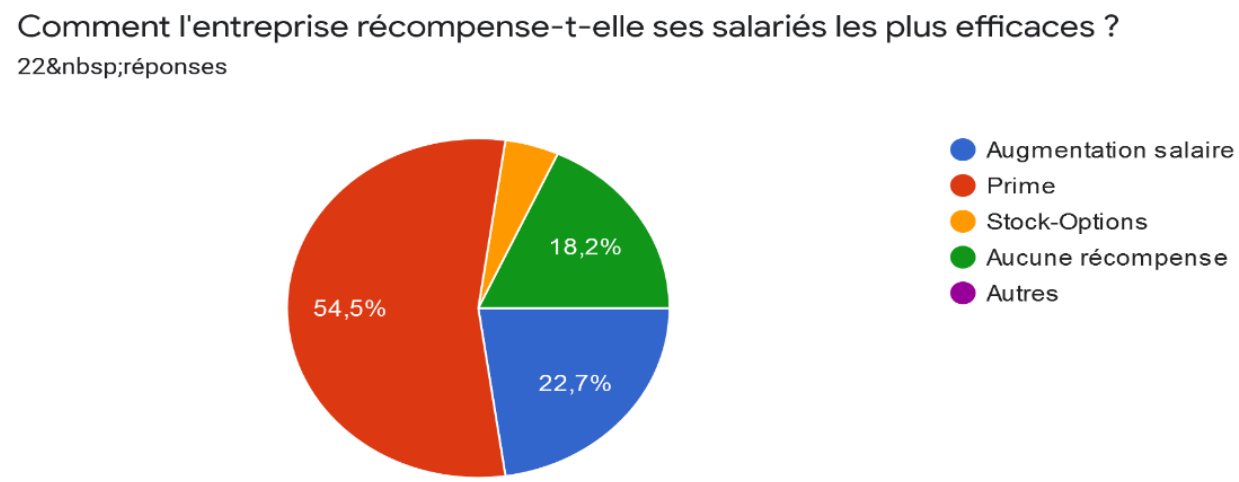

We can discover that $80 \%$ of Guyanese companies motivate their staff through rewards. Reward is the most common method used towards employees. 54.5\% offer a merit reward for objectives achieved. Indeed, this method will be more obvious in the commercial sectors (real estate agency, bank, dealer, insurance) or when selling a product. The commission earned ensures a profitable distribution. This means is then a source of motivation allowing to increase monthly or yearly the level of income. 
The salary increase represents $22.7 \%$ of the companies that do so. Moreover, it is more direct and generally followed by a hierarchical promotion. This favours the employee who obtains more power and compensation. In this case, he is more motivated to gradually move up the ladder and reach the top of the staff hierarchy.

It should be noted that $18.2 \%$ of companies do not practice any method of motivation within their company. This management style is turning against the owners of these companies, because employees who have no recognition at work are in the starting position, as they encounter better opportunities. These companies are experiencing sectoral difficulties.

\section{FIGURE 9 \\ MODE OF GOVERNANCE}

Quel est la politique de l'entreprise?

23\&nbsp;réponses

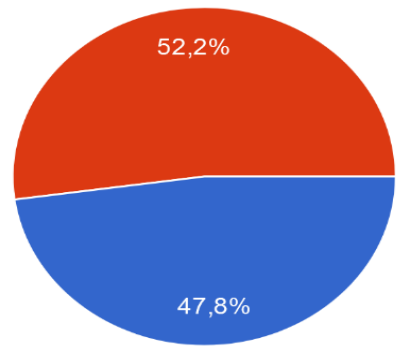

Maximisation actionnariale

Maximisation partenariale

The vast majority of companies turn to partnership governance, which represents $52.2 \%$ compared with $47.8 \%$ for shareholder governance. The objective of this type of governance is the search for profit, considering that in order for the company to make a profit, all partners linked to the profit must share it equitably.

Obviously, profit sharing generates a lesser gain for the shareholder. Consequently, the partners are invited to invest more in order to be more efficient with the objective of benefiting from a higher return from the shareholders.

With regard to shareholder governance, it is focused on the creation of shareholder value, considered as the sole beneficiary of the residual claim. It may be assumed that this method can hardly be appreciated by all the partners who work without necessarily achieving recognition.

Business owners must then put in place a set of elements for the control of their managers and employees to avoid economic and commercial exclusion. The relationship between shareholders and employees are facing the risk of deterioration and the resurgence of conflicts. The employees are not, however, turned towards the financial aspect, but aspire to have the profits of the companies participate in part in the improvement of working conditions. The degree of corporate social responsibility remains to be examined.

In the long term, this vision of the company raises the issue of the nature of governance for shareholders. It is impossible to animate corporate performance in social working conditions that are not very motivating for employees. 
THE PLACE OF THE EMPLOYEE IN THE DECISION-MAKING PROCESS

Les salariés participent-ils à la prise de décision?

22 réponses

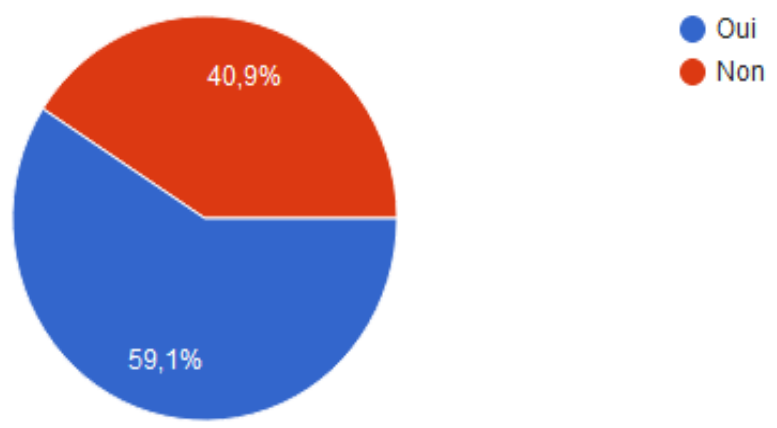

Generally, employees have a say in the decision-making process. Approximately $60 \%$ of companies have representatives participating in strategic meetings.

More specifically, these actions prove that important decisions are not only in the interests of the shareholders or managers who are in executive power. The staff could take corrective actions to ensure that these interests turn instead to the interest of the company.

On the other hand, $40.9 \%$ of companies in French Guiana prefer to exclude staff when making decisions. This choice is not a bad one, however, in view of the fact that the executive power makes decisions in favour of the social interest. Otherwise, it risks provoking conflicts and, more particularly, social movements that lead to a slowdown in company performance.

\section{FIGURE 11 \\ COMMUNICATION WITHIN THE COMPANY}

Considérez vous que la communication en interne soit efficace?
22\&nbsp;réponses

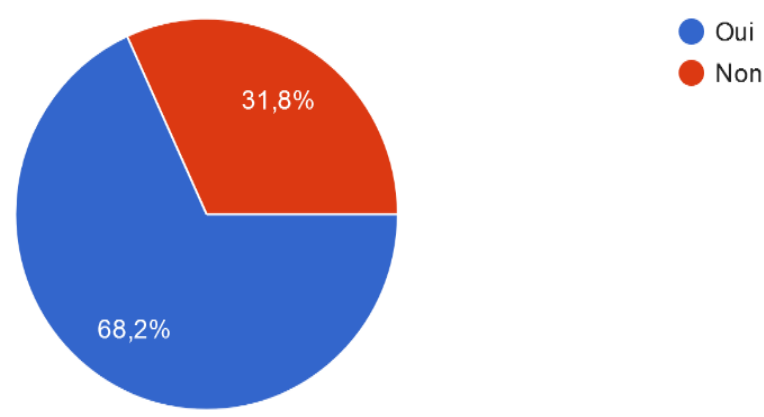

Usually, communication between the different parties in the companies goes smoothly. It is diffused in a fast way, without any asymmetry of information in order to penalize others. With an informational efficiency rate of $68.2 \%$, we can assume that in terms of data reliability, the company has the important information in time. 
FIGURE 12

PERCENTAGE OF OPINIONS FOR THE DECISION MAKING

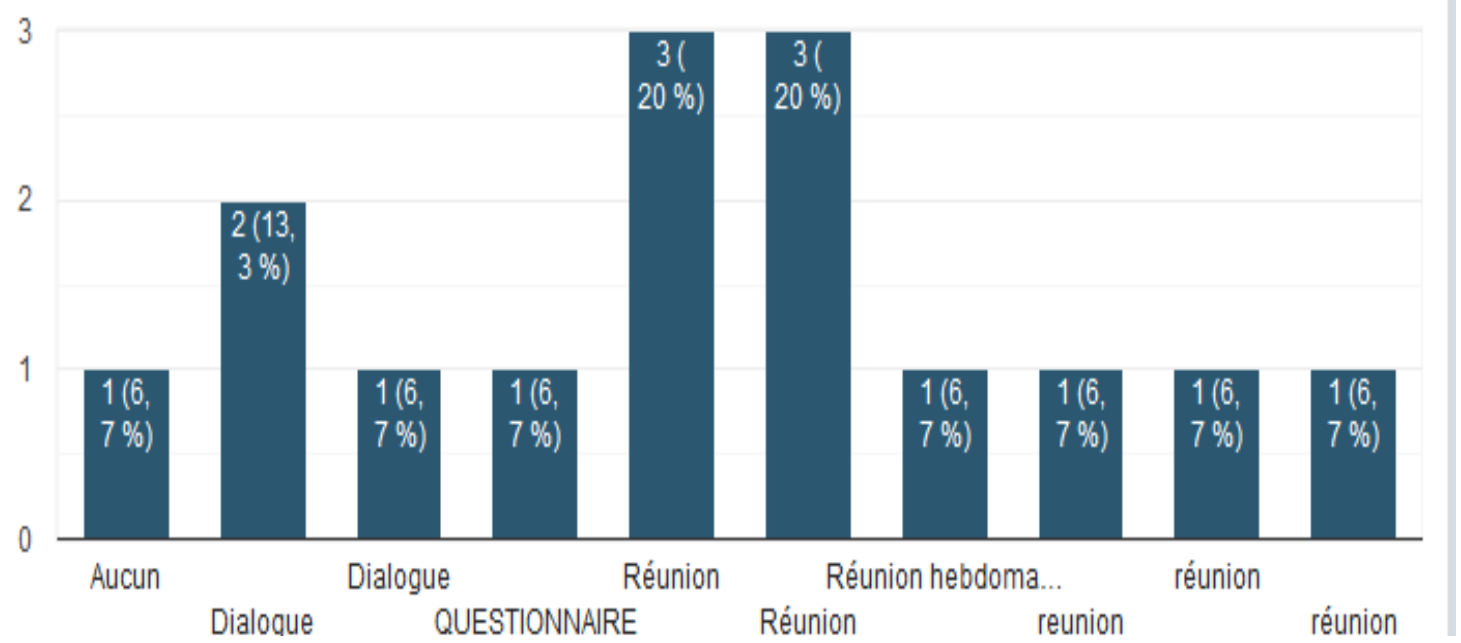

The most common mechanism for getting information across is the meeting. This will allow all parties to come together and share their opinions for decision making.

Benefit Management

FIGURE 13

DISTRIBUTION OF THE ANNUITY

Il y a-t-il une distribution de la rente organisationnelle au sein de entreprise?

23 réponses

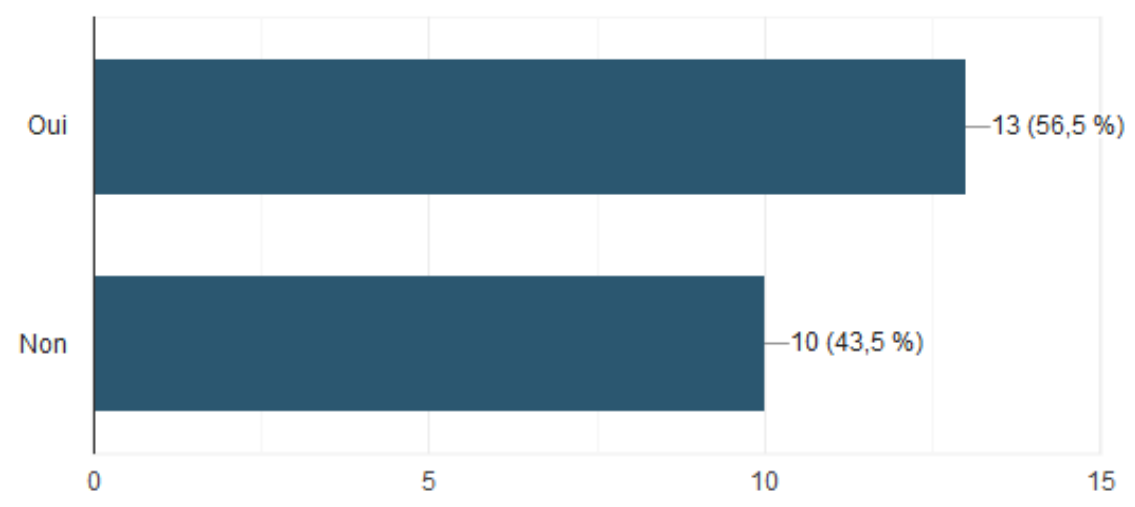

The organizational rent is generally distributed across all companies. For $56.5 \%$ of companies, profitability is beneficial to stakeholders, while $43.5 \%$ of companies decide not to share it. This indication shows that most companies have a partnership vision. This conception of governance leads partners to become more involved in profit realization. Their involvement leads to optimal company performance. 


\section{FIGURE 14 \\ DISTRIBUTION OF THE ORGANIZATIONAL RENT}

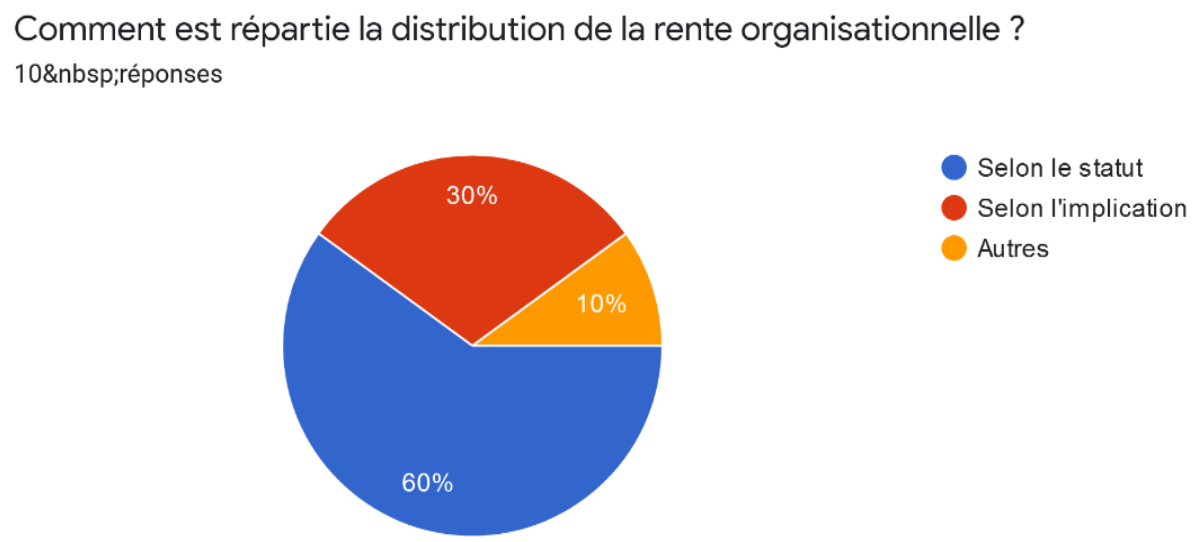

This result reflects the fact that companies that have a governance based on a partnership vision do not distribute dividends proportionally. Indeed, in $60 \%$ of cases, the distribution is made in the form of a status within the company. This way is somewhat discriminatory for employees who are at the bottom of the company hierarchy and who are generally the first to work for the smooth running of the company. Enforcement personnel could complain about their fate and no matter how committed they are to the smooth running of the company and the realization of profit, they always get the same benefit.

Contrary to the distribution of profitability according to status, the one linked to involvement obliges each employee to be involved in profit maximization in order to get merit pay. This method does not lead to exclusion between the different partners of the company.

\section{Concluding Remarks}

In the course of this study, it proved fundamental to go back to the different theories of governance. The core of the approach to value and wealth creation leads to an understanding of the dynamics of progress and performance. It reveals important characteristics. Indeed, value is built from the outset precisely around the financial model. Then, gradually, the value of the stakeholders appears. A new breath of life is breathed into the productive organization by giving priority to human capital.

By focusing on the elements highlighted, identifying the governance trend in Guyanese companies and the problems generated and to be solved, imposes the use of diverse and complex methodologies that do not always unilaterally satisfy the stakeholders' approach, management objectives and guarantees on the sincerity of the power of governance over the social interest.

The path followed leads to the observation of two trends:

- The shareholder vision is at the origin of social movements. Conflicts of interest triggering opportunistic behavior have strong repercussions on corporate earnings. Hence, the weak development of companies is in disconnection with the best returns. The poor business climate of 2017 in French Guiana, weakening performance, results in disrupted shareholder governance. Firms with a strong employee shareholding have conducted advantageous negotiations such as reducing expenses and investment support from monetary and financial institutions. This form of governance clearly shows that the social interest is not a priority for the shareholder.

- The partnership vision based on the social interest of the company is grappling with the solidarity of shareholders who are not the only residual creditors and the organizational profit to be shared among the stakeholders. The latter have often helped to support the company, accepting to bear sacrifices in times of crisis to avoid market exit, restart production and return 
to profitability. This trend in French Guyana is expressed by the highly participative behaviour of the parties in company strategies. It is therefore the values of equity that motivate the parties.

In our case study, the aim was to determine the company's environment, in the face of opportunistic employee behavior, conflict management, employee satisfaction and the distribution of organizational rent, through the survey we conducted among 22 companies.

Thus, from our results, we deduce that in French Guyana most companies adopt partnership governance, that's to say $52.2 \%$. The other proportion, a level of $47.8 \%$, is marked by shareholder governance. For the majority of companies, the objective of the managers is the development of the company. The search for performance is linked to the objective of profit to be distributed to the various stakeholders. The best way to motivate employees is to grant them a bonus. 54.5\% of companies apply this principle. The other means is a salary increase, which concerns $22.7 \%$ of the companies. Both of these methods are very well received by employees. This is an indicator of good management.

However, the distribution of profit, which should lead to a decrease in conflicts, is triggering social movements. For $55 \%$ of the companies that endure conflicts, the main cause is the distribution of profitability, which is estimated at a rate of $45 \%$. The poor management of profitability does not validate Ansoff's theory in French Guyana. Indeed, the distribution of profit is not established in an equitable manner. Indeed, $60 \%$ of companies distribute profits according to the status of their employees.

Approximately $60 \%$ of companies include their employees when making decisions. This indicates that decisions are not necessarily made to the detriment of the social interest. Corporate governance prefers to converge strategies with employees before implementing them. The theories of Etzioni, Freeman and Evan have been partially validated. Employees are part of the decision-making system, hence shareholders are not the only ones to make decisions. This mode of operation generates partial employee confidence.

The trend revealed by the sample studied sheds light on corporate governance in French Guyana. However, other studies could be addressed in this direction.

\section{ENDNOTE}

1. This topic presented here is a part of program of research on management of firms in the context of South America, particularly in French Guyana in progress in the framework of the team called BETA EMADD BIO of the laboratory MINEA UR 7485 of the university of French Guyana.

\section{REFERENCES}

Albouy, M. (2016). Chronicle of finance and corporate governance. Moncton, Montreal, Canada. Ansoff, I. (1968). Corporate development strategy. Macmillan Pblishers, New York.

Antienne, A. (2005). Analyse économique du droit de l'actionnariat salarié. Edition Bruylant-LGDJ Bruxelles.

Aoki, M. (1984). The Cooperative Game Theory of the Firm. Oxford University Press, Oxford.

Aoki, M. (1984). Toward an Economic model of the Japanese firm. Journal of Economic Literature, 28(1), 1-27. American Economic Association.

Armstrong, C.S, Guay, W.R., \& Weber, J.P. (2010). The rôle of information and financial reporting in corporate governance and debt contracting. Journal of Accounting and Economics, 50, 179-234.

Arrow, K. (1973). Social responsibility and Economics Efficiency. Mac Graw Hill Publihers, Montréal, Canada.

Baumol, W. (1959). Business behavior, value and growth. New York, Mac Millan, USA.

Berle, A., \& Means, G. (1932). The modern corporation and private property. New York; Harcourt, Brace and World, USA.

Berle, A., \& Means, G. (1998). La gouvernance d'entreprise. Economica. France.

Brandenburger, A.M., \& Stuart, H.W. (1996). Value-based business strategy. Mac Millan, USA.

Cabin, P. (2018). Best practices for creating value. Springer, Montreal, Canada. 
Caby, J., \& Hirigoyen, G. (2014). Value creation and corporate governance. Mac Graw Hill Publihers, Montréal, Canada.

Caby, J., \& Hirigoyen, G. (2005). La création de valeur dans l'entreprise. Edition Economica.

Chandler, A. (1977). The Visible Hand. The Managerial Revolution in American Business. Mac Graw Hill, USA.

Chandler, A.D. (1988). La main invisible des managers. Economica, Paris, France.

Charreaux, G., \& Desbrières, P. (1998). Gouvernance des entreprises : La valeur partenariale contre la valeur actionnariale. Economica, Paris, France.

Charreaux, G. (1998). Le rôle de la confiance dans le système de gouvernance de l'entreprise. Economica. Paris, France.

Charreaux, G. (2000). La théorie positive de l'agence : Positionnement et apports (Positive agency theory : positioning and contributions). International Conference, Sweden.

Charreaux, G. (2003). Michael C. Jensen: The pioneer of organizational finance. [Working Papers] Juillet, Londres.

Charreaux, G. (2005). Toward a behavioural corporate governance theory: An exploratory view. Cahier du FARGO n ${ }^{\circ}$ 1050601, June, France.

Coase, R.H. (1937). The Nature of the Firm. Mac Millan Publishers, New York, USA.

Montmorillon, B. (1986). Les groupes industriels. Economica. Paris, France.

Cyert, R.M., \& March, J.G. (1963). A behavioral theory of firm. SSRN, Elsevier, University of Illinois at Urbana-Champaign's Academy for Entrepreneurial Leadership Historical Research.

Demsetz, H., \& Lehn, K. (1985). The structure of corporate ownership: Causes and Consequences. Mc Milan.

Demstz, H. (1988). The Theory of the Firm Revisited. Oxford.

Desbrières, P.H. (1991). Financial participation, stock options and company buyouts by employees. Internations Congress, Findland.

Desbrières, P.H. (1997). The role of non-executive employee share ownership in the corporate governance system. Mac Graw Hill, New York, USA.

Desbrières, P.H. (1998). Gouvernance des entreprises : Valeur partenariale contre valeur actionnariale. Université of Burgundy, Mac Graw Hill, New York, USA.

Erikson, M., Hanlon, M., \& Maydew, E.L. (2006, January). Is there a link between executive equity incentives and accounting fraud. Journal of Accounting Research, 23. Wiley Publishers.

Fama, E., \& Jensen, M.C. (1983b). Agency Problems and Residual Claims. De Boeck, Montréal, Canada.

Finet. (2005). Gouvernance d'entreprise, aspects manageriaux, comptables et financiers. De Boeck Supérieur, France.

Freeman, R.E. (1984). Strategic Management: A stakeholder Approach. Mc Graw Hill, New York.

Freeman, R.E. (2000). Business Ethics at the Millennium, 18(3), 350-367. New York.

Garfatta, R. (2010). Actionnariat salarié et création de valeur dans le cadre d'une gouvernance actionnariale partenariale : Application au contexte français. Thèse de Doctorat en Sciences de Gestion, Université de Tunis El Manar, Université de Dijon, France.

Kawley, J., \& William, A. (2000). The émergence of universal owners; Some implications of institutional equity ownership. Challenge, 43(4). Taylor and Francis Publishers. London.

Harris, J., \& Brmiley, P. (2007). Incentives to cheat: The influence of executive compensation and firm performance on financial misrepresentation. Organisation Science.

Hill, C.W., \& Jones, T.M. (1992). Stakeholder-agency theory. Journal of Management Studies, 29, 131154.

Hollandts. (2007). Les effets de participation des salariés sur la performance de l'entreprise: Tests empiriques et proposition de modèle théorique. Thèse de Doctorat en Sciences de Gestion, Université Jean-Moulin, Lyon 3, France.

Jean, S., \& Le Heran, J. (2004). le management équitable (the new management method).

Jensen, M.C., \& Meckling, W.H. (1998). Coordination, Control and the Management of Organizations. Eyrolles, France. 
Jensen, M.C. (2004). The Agency Costs of Overvalued Equity and the Current State of Corporate Finance. Mc Graw Hill, New York.

Jensen, M.C. (2001). Value maximization, Stakeholder Theory and the Corporate Objective Function. Mc Graw Hill, New York.

Jensen, M.C. (1991). Corporate Control and the Politics of Finance. Mc Graw Hill, London.

Jensen, M.C., \& Mekling, W.H. (1976). Theory of The Firm: Managerial Behavior, Agency Costs and Ownership Structure. Mc Graw Hill, London.

Johnson, D.W., \& Johnson, R.T. (2009). An educational psychology sucess story: Social interdependance theory and cooperative learning. American, educational Research Association.

Marris, R. (1964). The economic theory of managerial capitalism. London Macmillan.

Marx, K. (1864). Karl Marx pangermaniste et l'AIT. In J. Guillaume.

Marx, K. (1875). Le capital. Editions Sociales, Paris, France.

Mayer, C. (1996). Corporate Governance, Competition and Performance. International Congress, Greece.

Montmorillon, B. (2002). The challenge of theoretical discernment. In K. Michel, Les défis du management (editions Liaisons). Rueil-Malmaison, France.

Moore, G. (1999). Tinged Shareholder Theory: Or what's so Special about Stakeholders.

Naciri, A. (2011). Treaty of governance.

Ndofor, H.A., Simon, D.G., \& He, X. (2014). Utilizing the firm's resources: How Tmt heterogeneity and resulting faultlines affet Tmt tasks. Stategic Management Journal, 36(11).

Frederic. (2014). Theory and practice of corporate governance. Springer, Montréal, Canada.

Perroux, F. (1957). Théorie générale du progrès économique (General Theory of Economic Progress). France.

Plihon, P. (2003). Le nouveau capitalisme. Collection Repères, Edition La Découverte, Paris, France.

Raviv, A., \& Harris, M. (1991). The theory of capital Structure Association. Journal of Finance, Journal of the American Finance.

Roselé Chim. (2008). International growth pole, innovation effect of the development of the European space industry in French Guiana. Canadian Journal of Development Studies, 31(1-2). Ottawa, Canada.

Roselé Chim. (2017). Economic intelligence and industrial development of territories: Some aspects of sustainability. [Working papers]. BETA MINEA EA 7485, Cayenne: University of French Guiana, France.

Roselé Chim. (2017). Statistical analysis as a principal component over a long period of time. Paper for the International Conference on Management and Governance. University Titu Maresco, Bucarest, Roumania.

Ross, S.A. (1973). The economic theory of agency : The principal's problem. Ewin A., Seligman Publishers, London.

Seligman, H., \& Inrvin, V. (1997, June). A survey of corporate governance. Journal of Finance, 11(2).

Simon, C.J., \& Sullivan, M.W. (1993). The Measurement and Determinants of Brand Equity: A Financial Approach. Marketing Science, 12(1), 28-52. University of Chicago.

Smith, A. (1776). An inquiry into the nature and causes of the wealth of nations. Ewin A., Seligman Publishers, London.

Thnag, N.N., \& Buyens, D. (2008). Training, organizational strategy and firm performance. Economics and International Business Research Conference, December 10-13, Miami, USA.

Williamson, O.E. (1988). Technology and transaction cost economics: A reply. Journal of Economic Behavior and Organization, 10(3), 335-363.

Williamson, O.E. (1991). Economic institutions, spontaneous and intentional governance. Mac Millan, USA. 


\section{APPENDIX 1}

Results of the case study of a sample of 22 companies in French Guyana. Paul Roselé Chim, 2020. Beta Emadd Bio, MINEA UR 7485. University of French Guyana.

Comment évaluez vous le bien être de l'entreprise ?

22 réponses

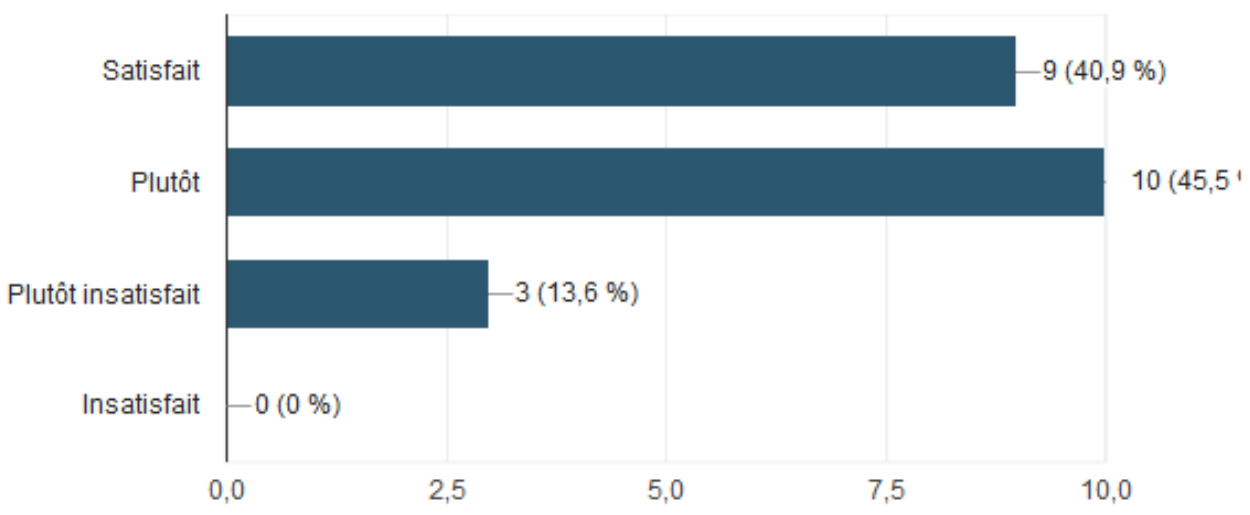

Avez vous confiance en votre entreprise?

22\&nbsp;réponses

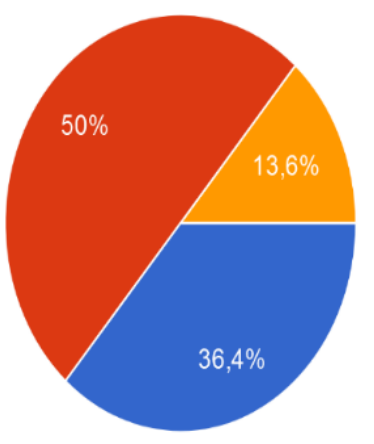

Absolument

Plutôt

Pas vraiment

Pas du tout 
Vous sentez vous reconnu(e) dans votre travail ?

22 réponses

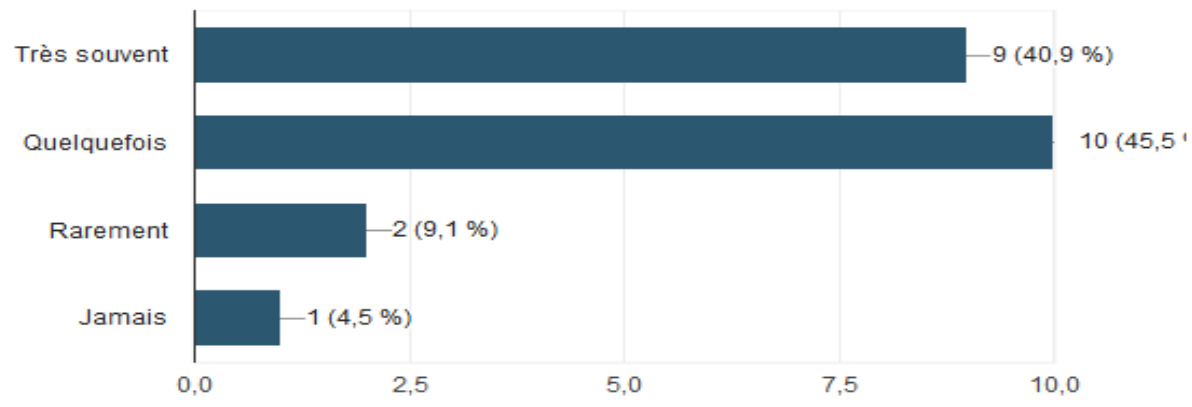

Bénéficiez vous d'un conseil d'administration?

22\&nbsp;réponses

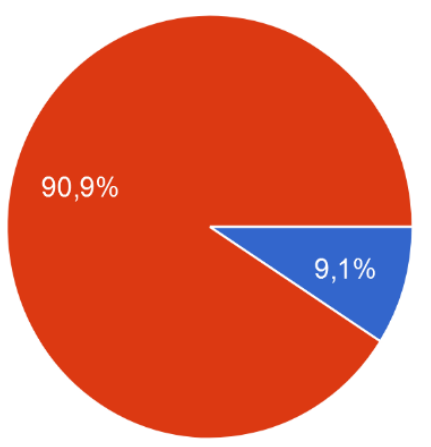

Non

Que pensez-vous du style de leadership?

22\&nbsp;réponses

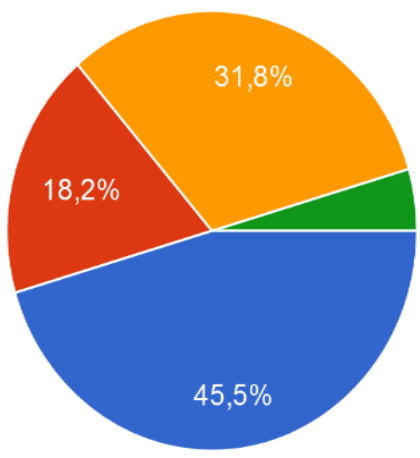

Autoritaire

Paternaliste

Démocratique

Autres 
Quelle place avez-vous au sein de votre entreprise?

22\&nbsp;réponses

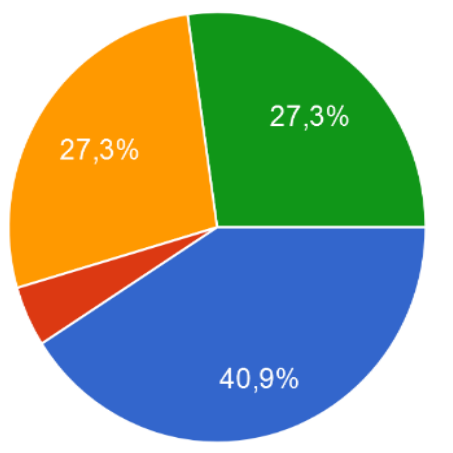

Dirigeant

Actionnaire

Cadre

Salariés

Les objectifs opérationnels des processus sont-ils atteints, presque toujours, toujours depuis 3 ans, plus de 5 ans?

22\&nbsp;réponses

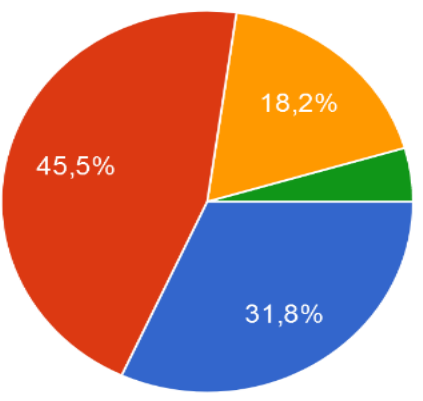

Pas toujours atteints.

Généralement atteints à court terme.

Toujours sauf une ou deux exceptions sur 3 ans.

Toujours depuis 3 ans

- Toujours depuis 5 ans. 
L'entreprise a-t-elle une culture de la performance économique et de la création de la valeur?

22\&nbsp;réponses

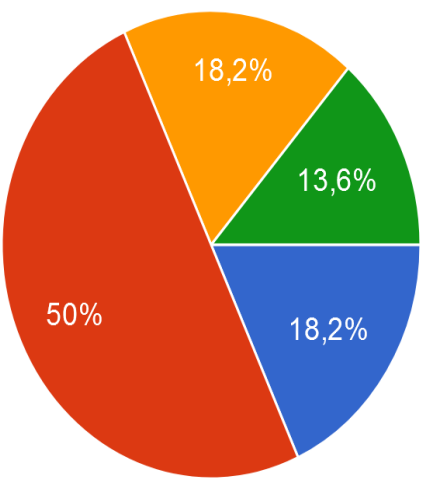

Non.

Partiellement, la culture de la création de valeur n'est pas systématique.

Oui, des indicateurs de performance économique existent et sont partagés.

Oui, les résultats attendus et constatés sont maîtrisés et partagés.

La performance opérationnelle et la création de valeur sont-elles gérées à travers la performance des processus?

22\&nbsp;réponses

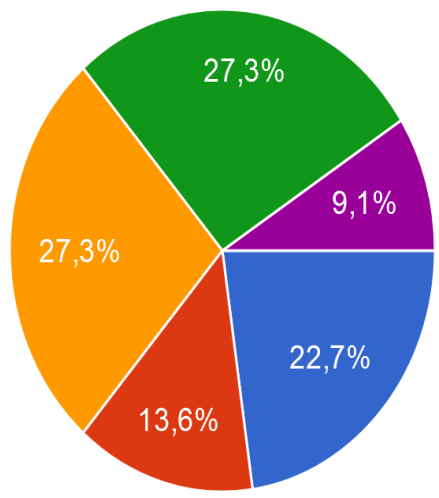

Non.

Non, ou seulement au coup par coup par des actions spécifiques.

Oui, la performance opérationnelle et la création $d . .$.

La performance opérationnelle et la création de valeur sont...

Oui, la performance opérationnelle et la création $d$... 
Comment évaluez-vous la satisfaction du client?

18 réponses

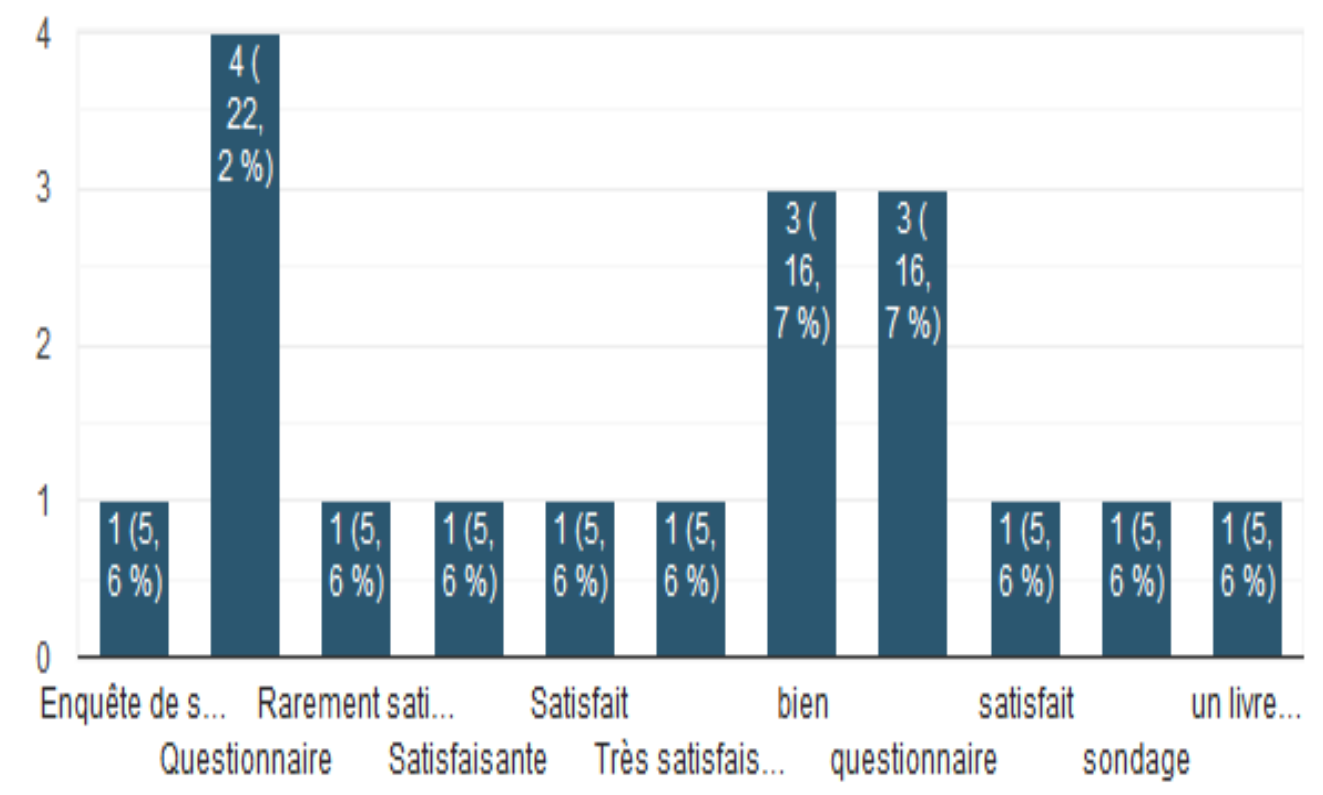

si oui a-t-elle été récurrente?

7\&nbsp;réponses

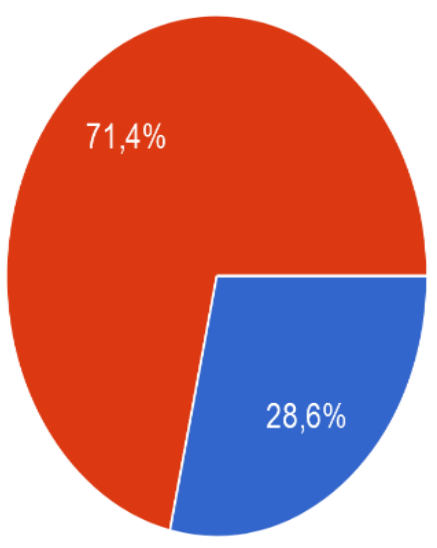

Oui

Non 
Etait-il de la part des?

7\&nbsp;réponses

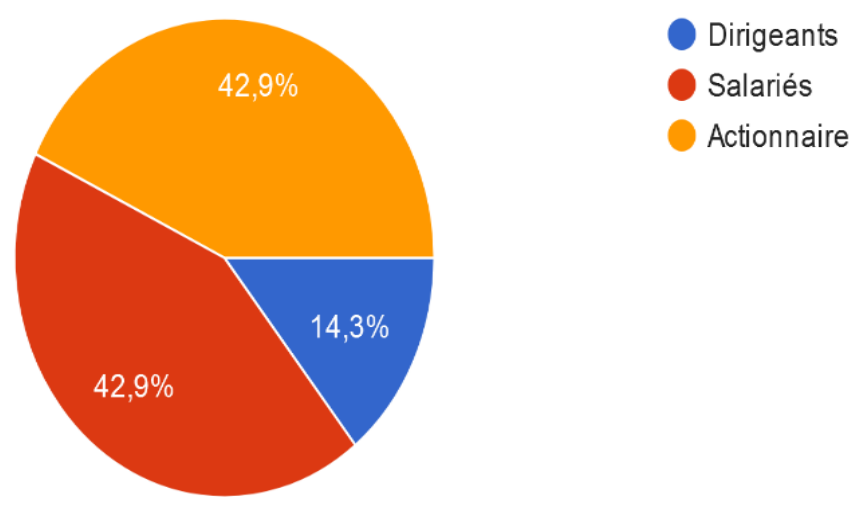

\section{APPENDIX 2}

Questionnaire on the impact of corporate governance within companies in French Guyana. Paul Roselé Chim, 2020. Beta Emadd Bio, MINEA UR 7485. University of French Guyana.

\section{PLEASE FILL IN THIS QUESTIONNAIRE AS ACCURATELY AS POSSIBLE}

\section{COMPANY PRESENTATION}

Company Name Click or press here to enter text.

Location Click or click here to enter text.

Creation Date Click or click here to enter text.

1. Are you a subsidiary?

$\square$ Yes $\square$ No

If yes, which group do you belong to ? Click or press here to enter text.

2. Sector of activity :

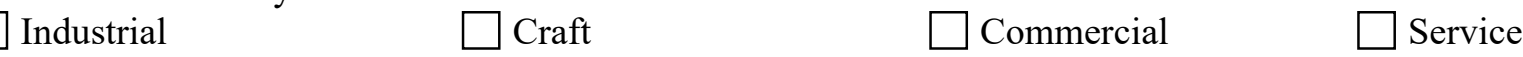

3. Activity Area : Click or press here to enter text.

4. Type of business :

Shareholder

$\square$ SME-SMI

$\square$ Family

VSE 


\section{Conflict management}

5. Has the company ever faced a conflict with employees ?

$\square$ Yes

$\square$ No

6. If yes, what was the cause of this conflict?

Distribution of pension $\quad \square$ Poor working conditions $\quad \square$ Other

7. What methods are used to resolve conflicts within the company?

$\square$ Social dialogue $\square$ Management tool $\square$ Cooperative game

\section{INTERNAL MANAGEMENT}

8. Do you have a Board of Directors ?

$\square$ Yes $\square$ No

9. How does the company reward its most effective employees ?
Salary
$\square$ Bonuses
Stock Options

10. How do you assess the well-being of the company?
Very good
Somewhat
Not really
Not at all

11. Do you have confidence in your company?

Absolutely $\square$ Somewhat

Not really

Not at all

12. Do you feel recognized in your work?
Very often
Sometimes
Rarely
Never

13. What do you think of the leadership style?

Autoritarism

$\square$ Paternalistic

Démocratic

Other

14. What is the company's policy?

$\square$ Shareholder Maximization $\square$ Partner Maximization

15. Are employees involved in decision-making?

$\square$ Yes $\square$ No

16. What is your place in your company?
Manager
$\square$ Shareholder
Executive
Employees

17. Do you consider internal communication to be effective?

$\square$ Yes $\square$ No

If Yes, what mechanisms are in place? Click or press here to enter text.

18. How do you rate customer satisfaction? Click or click here to enter text 
19. Does the company have a culture of business performance and value creation?

$\square$ No. $\square$ Partially, the culture of vale creation is not systematic.

$\square$ Yes, economic performance indicators exist and are shared.

Yes, the expected and observed results are controlled and shared.

20. Are the operational objectives of the processes achieved, almost always, always for 3 years, more than 5 years?

$\square$ Not always achieved. $\quad \square$ Generally achieved in the short term.

$\square$ Always with one or two exceptions over 3 years. $\square$ Always for 3 years.

Always for 5 years

21. Are operational performance and value creation managed through process performance?

$\square$ No. $\square$ No, or only on an ad hoc basis through specific actions.

$\square$ Yes, operational performance and value creation are measured and broken down by process.

$\square$ Operational performance and value creation are measured, controlled and anticipated through process performance management.

$\square$ Yes, operational performance and value creation are measured, controlled, anticipated and recognized as a benchmark by the market.

\section{BENEFIT}

22. Has the company ever faced expropriation?

$\square$ Yes $\square$ No

If yes, was it recurrent?

Yes

No

23. Was it from the ?

$\square$ Manager $\square$ Employees $\quad \square$ Other

24. Is there an organizational rent distribution within your company?

Yes

$\square$ No

25. Is there an organizational rent distribution within your company?

26. How is the distribution of the organizational annuity distributed ?

According to status

According to involvement $\square$ Other 